\title{
Downward cloud venting of the central African biomass burning plume during the West Africa summer monsoon
}

\author{
Alima Dajuma ${ }^{1,3}$, Kehinde O. Ogunjobi ${ }^{1,4}$, Heike Vogel $^{2}$, Peter Knippertz ${ }^{2}$, Siélé Silué ${ }^{5}$, Evelyne Touré N'Datchoh ${ }^{3}$, \\ Véronique Yoboué $e^{3}$, and Bernhard Vogel ${ }^{2}$ \\ ${ }^{1}$ Department of Meteorology and Climate Sciences, West African Science Service Centre on Climate Change and Adapted \\ Land Use (WASCAL), Federal University of Technology Akure (FUTA), Ondo State, Nigeria \\ ${ }^{2}$ Institute of Meteorology and Climate Research, Karlsruhe Institute of Technology (KIT), Karlsruhe, Germany \\ ${ }^{3}$ University Félix Houphouët Boigny, Abidjan, Côte d'Ivoire \\ ${ }^{4}$ Federal University of Technology Akure (FUTA), Ondo State, Nigeria \\ ${ }^{5}$ Université Peleforo Gon Coulibaly, Korhogo, Côte d'Ivoire
}

Correspondence: Alima Dajuma (alima.dajuma@yahoo.com)

Received: 29 June 2019 - Discussion started: 9 August 2019

Revised: 3 April 2020 - Accepted: 4 April 2020 - Published: 7 May 2020

\begin{abstract}
Between June and September large amounts of biomass burning aerosol are released into the atmosphere from agricultural fires in central and southern Africa. Recent studies have suggested that this plume is carried westward over the Atlantic Ocean at altitudes between 2 and $4 \mathrm{~km}$ and then northward with the monsoon flow at low levels to increase the atmospheric aerosol load over coastal cities in southern West Africa (SWA), thereby exacerbating air pollution problems. However, the processes by which these fire emissions are transported into the planetary boundary layer (PBL) are still unclear. One potential factor is the large-scale subsidence related to the southern branch of the monsoon Hadley cell over the tropical Atlantic. Here we use convection-permitting model simulations with COSMOART to investigate for the first time the contribution of downward mixing induced by clouds, a process we refer to as downward cloud venting in contrast to the more common process of upward transport from a polluted PBL. Based on a monthly climatology, model simulations compare satisfactory with wind fields from reanalysis data, cloud observations, and satellite-retrieved carbon monoxide (CO) mixing ratio. For a case study on 2 July 2016, modelled clouds and rainfall show overall good agreement with Spinning Enhanced Visible and InfraRed Imager (SEVIRI) cloud products and Global Precipitation Measurement Integrated MultisatellitE Retrievals (GPM-IMERG) rainfall estimates. However, there is a tendency for the model to produce too much
\end{abstract}

clouds and rainfall over the Gulf of Guinea. Using the $\mathrm{CO}$ dispersion as an indicator for the biomass burning plume, we identify individual mixing events south of the coast of Côte d'Ivoire due to midlevel convective clouds injecting parts of the biomass burning plume into the PBL. Idealized tracer experiments suggest that around $15 \%$ of the CO mass from the $2-4 \mathrm{~km}$ layer is mixed below $1 \mathrm{~km}$ within $2 \mathrm{~d}$ over the Gulf of Guinea and that the magnitude of the cloud venting is modulated by the underlying sea surface temperatures. There is even stronger vertical mixing when the biomass burning plume reaches land due to daytime heating and a deeper PBL. In that case, the long-range-transported biomass burning plume is mixed with local anthropogenic emissions. Future work should provide more robust statistics on the downward cloud venting effect over the Gulf of Guinea and include aspects of aerosol deposition.

\section{Introduction}

The interest in air pollution over southern West Africa (SWA) has grown substantially in recent years (Knippertz et al., 2015). Population growth, urbanization, and industrialization have led to increasing local emissions from various sources in addition to natural ones. For instance, coastal city development in SWA is leading to more traffic and fuel consumption (Doumbia et al., 2018). Anthropogenic emis- 
sions are expected to continue increasing if no regulations are implemented (Liousse et al., 2014). Domestic fires, traffic, and waste burning are the most important sources of pollution in West Africa (Marais and Wiedinmyer, 2016; Bahino et al., 2018; Djossou et al., 2018). In the framework of the Dynamics-Aerosol-Chemistry-Cloud Interactions in West Africa (DACCIWA; Knippertz et al., 2015a) field campaign in SWA during June-July 2016 (Flamant et al., 2018b), measurements of the French Service des Avions Français Instrumentés pour la Recherche en Environnement (SAFIRE) ATR-42 aircraft showed fairly high background concentrations (i.e., outside of urban plumes) with $\mathrm{PM}_{1}$ mass concentrations dominated by secondary organic compounds that contribute $53 \%$ to the total aerosol mass (Brito et al., 2018). For the urban pollution plumes of Abidjan, Accra, and Lomé, they found a doubling of $\mathrm{PM}_{1}$ mass concentrations. Air pollution is a main concern for human health leading to respiratory and other diseases (Lelieveld et al., 2015), but it may also affect local meteorology. For instance, using model sensitivity experiments, Deetz et al. (2018) showed that increasing aerosol loadings can lead to a reduced inland penetration of the Gulf of Guinea maritime inflow (Adler et al., 2019) and a weakening of the nocturnal low-level jet over SWA.

During the summer West African monsoon (WAM), the atmosphere over SWA is characterized by a mixture of pollutants from different sources as highlighted by Knippertz et al. (2017). In addition to the local pollution, long-range transport of dust from the Sahel and the Sahara as well as biomass burning aerosol from central and southern Africa affects the atmospheric composition. Mineral dust has been shown to affect radiation, precipitation, and many WAM features (e.g., Konare et al., 2008; Solmon et al., 2008; Stanelle et al., 2010; Raji et al., 2017; N'Datchoh et al., 2018). During this period, biomass burning is widespread in central and southern Africa, when plumes are carried westward by a jet between 2 and $4 \mathrm{~km}$ (Barbosa et al., 1999; Mari et al., 2008), while in West Africa activity peaks during the dry season from October to March (N'Datchoh et al., 2015). Biomass burning is an important source of aerosols and trace gases, with an estimated combined emission of several thousand teragrams per annum $\left(\mathrm{Tg} \mathrm{a}^{-1}\right)$ for tropical areas (Barbosa et al., 1999; van der Werf et al., 2003; Ito and Penner, 2004). For instance the estimated carbon emissions from both tropical fires and fuel wood use was 2.6 $\mathrm{Pg} \mathrm{C} \mathrm{a}^{-1}$ over the period 1998-2001 (van der Werf et al., 2003). Hao and Liu (1994) estimated that almost half of tropical biomass burning emissions come from Africa, with savanna fires contributing up to $30 \%$ to the global total and $64 \%$ to the African total. During the DACCIWA field campaign, a surprisingly high level of pollution was observed over the sea upstream of SWA. Haslett et al. (2019) found a significant mass of aged accumulation mode aerosol in the planetary boundary layer (PBL) over both continent and ocean. According to modelling work by Menut et al. (2018), biomass burning from central and southern Africa increases the level of air pollution in urban cities such as Lagos and Abidjan by approximately $150 \mathrm{\mu g} \mathrm{m}^{-3}$ for carbon monoxide (CO), $10-20 \mu \mathrm{g} \mathrm{m}^{-3}$ for ozone $\left(\mathrm{O}_{3}\right)$, and $5 \mu \mathrm{g} \mathrm{m}^{-3}$ for particulate matter with diameters smaller than $2.5 \mu \mathrm{m}\left(\mathrm{PM}_{2.5}\right)$.

An important and open question is the mechanism by which the biomass burning aerosols from central Africa get from the layer of midlevel easterlies into the PBL. Das et al. (2017) reported that global aerosol models tend to simulate a quick descent to lower levels just off the western coast of Africa, while Cloud-Aerosol Lidar with Orthogonal Polarization (CALIOP) observations suggest that smoke plumes continue their horizontal transport at elevated levels above the marine boundary layer. The strength and speed of subsidence vary amongst models and subregions. The hypothesis we investigate in this paper is that clouds play a considerable role in the downward mixing of biomass burning aerosol from the elevated plume. Most previous studies have focused on cloud-induced upward transport of aerosols and chemical species from close to their sources in the PBL to the free troposphere (e.g., Dickerson et al., 1987; Ching et al., 1988; Cotton et al., 1995). Using two-dimensional idealized simulations, Flossmann and Wobrock (1996) calculated the mass transport of trace gases across cloud boundaries and from the marine boundary layer into the free troposphere. The atmospheric condition was a well-mixed boundary layer up to about $500 \mathrm{~m}$ and above a moist layer of about $2.2 \mathrm{~km}$ capped by a very dry stable layer. They found that $60 \%$ of the mass of an inert tracer is exported due to convective clouds. The same paper also examines the transport of $\mathrm{SO}_{2}$ including chemical reactions showing that only a small fraction is dissolved and reacts in the aqueous phase, while substantial amounts of $\mathrm{SO}_{2}$ are redistributed by clouds (see also Kreidenweis et al., 1997). Using a 1-D entraining-detraining plume model with ice microphysics, Mari et al. (2000) studied the transport of $\mathrm{CO}$ (inert tracer), $\mathrm{CH}_{3} \mathrm{COOH}, \mathrm{CH}_{2} \mathrm{O}, \mathrm{H}_{2} \mathrm{O}_{2}$, and $\mathrm{HNO}_{3}$, and they compared the results with observations from the Trace and Atmospheric Chemistry Near the Equator-Atlantic (TRACE-A) campaign. Convective enhancement factors at 7-12 km altitude, representing the ratios of post convective to preconvective mixing ratios, were calculated for both observed and simulated cases. Observed (simulated) values were 2.4 (1.9) for $\mathrm{CO}, 11$ (9.5) for $\mathrm{CH}_{3} \mathrm{COOH}, 2.9$ (3.1) for $\mathrm{CH}_{2} \mathrm{O}, 1.9$ (1.2) for $\mathrm{H}_{2} \mathrm{O}_{2}$, and $0.8(0.4)$ for $\mathrm{HNO}_{3}$. Pickering et al. (1996) showed an upward transport of $\mathrm{CO}, \mathrm{NO}_{x}$, and hydrocarbon mixing ratios by convective clouds during the Brazilian phase of the TRACE-A experiment. Moreover, Yin et al. (2001) simulated trace-gas redistribution by precipitating continental convective clouds and found abundant highly soluble gases in their uppermost parts, while Halland et al. (2009) showed substantial vertical transport of tropospheric $\mathrm{CO}$ by deep mesoscale convective systems.

In contrast, rather few studies investigated the downward transport of elevated pollution through convective clouds. For the marine PBL, aerosol particles from the free tropo- 
sphere have been identified to serve as cloud condensation nuclei in stratiform clouds with cloud entrainment contributing up to $20 \%$ of the aerosol mass (Raes, 1995; Katoshevski et al., 1999). Over land, most studies concentrated on the Amazon rainforest. Based on campaign data during the wet season, Betts et al. (2002) showed that convective downdraughts rapidly transport air with high ozone down to the surface from around $800 \mathrm{hPa}$, suggesting a significant role of this process for the photochemistry of the PBL and surface ozone deposition. Gerken et al. (2016) even found evidence for transport of ozone-rich air from the midtroposphere to the surface, enhancing the volume mixing ratio in the boundary layer by as much as $25 \mathrm{ppbv}$ on the regional scale, while Wang et al. (2016) demonstrated the injection of high concentrations of small aerosol particles into the PBL by strong convective downdraughts. In more general terms, Jonker et al. (2008) proposed a refined view of mass transport by cumulus convection relevant for the dispersion of aerosol. According to them, the descending motion near the cloud environment is significant and rather different than in a distant cloud environment, which is characterized by more uniform and quiescent dry descending motion.

This study uses simulations with COSMO (COnsortium for Small-scale MOdelling) (Baldauf et al., 2011) coupled online with Aerosol and Reactive Trace gases (ART; Vogel et al., 2009) to investigate cloud-induced transport of biomass burning aerosols from midlevel tropospheric layers into the PBL over the Gulf of Guinea and SWA. A 1-month simulation for July 2016 (i.e., during the DACCIWA field campaign) over a large domain will be evaluated with available observational datasets and combined with a detailed highresolution case study, followed by idealized tracer experiments designed to quantify the vertical transport. The paper is organized as follows. Section 2 describes the satellite and reanalysis data as well as the model framework and simulation set-up used for this study. The model evaluation is presented in Sec. 3. In Sect. 4 the downward cloud venting process and its contribution to the vertical mixing of the biomass burning plume are assessed and discussed. Analysis of an artificial tracer to quantify the mass fraction of the biomass burning plume that mixes down into the PBL is given in Sect. 5. The last section presents a summary of the results and conclusions.

\section{Data and modelling}

\subsection{Observational data}

The following data from space-borne platforms and reanalysis are used for this study:

1. The Moderate Resolution Imaging Spectroradiometer (MODIS) is a key instrument on board the Earth Observing System (EOS) Terra satellites. The instrument views the entire Earth's surface every 1 to $2 \mathrm{~d}$ acquiring data in 36 spectral bands ranging in wavelengths from 0.4 to $14.4 \mu \mathrm{m}$. The MODIS product for cloud properties that we use is MOD08_E3 (Platnick et al., 2017). Amongst others, it contains $1^{\circ} \times 1^{\circ}$ grid-averaged values of cloud fraction averaged over the month of July 2016.

2. Measurements of Pollution in the Troposphere satellite (MOPITT) is used to derive $\mathrm{CO}$ volume mixing ratios. MOPITT measurements are performed in eight nadir-viewing spectral channels using a gas correlation spectroscopy technique with a horizontal resolution of $22 \mathrm{~km} \times 22 \mathrm{~km}$ (Clerbaux et al., 2008). A detailed description of the instrument and measurement technique can be found in Drummond and Mand (1996), Pan et al. (1998), and Edwards et al. (1999). The data are available at different height levels from the surface to $150 \mathrm{hPa}$. Global coverage is reached after 3 to $4 \mathrm{~d}$. MOPITT data have been shown to distinguish CO pollution from large cities and urban areas from background pollution using only thermal infrared information (Clerbaux et al., 2008) and perform even better using a combination of thermal infrared and solar radiation in the PBL (Buchwitz et al., 2007; Turquety et al., 2008). Kar et al. (2008) highlighted that retrievals in the lower troposphere over continental areas provide reasonable information on surface emissions of $\mathrm{CO}$, although the measurements suffer from strong thermal contrasts. According to Buchholz et al. (2017), MOPITT measurements overestimate relative to ground-based remotesensing Fourier transform infrared spectrometer data with a bias of less than $10 \%$ evaluated over 14 stations.

3. To represent standard meteorological fields, monthlymean ERA-Interim reanalysis data from the European Centre for Medium-Range Weather Forecasts (ECMWF) at a spatial resolution of $0.25^{\circ}$ are used for this study (Dee et al., 2011).

4. Daily sea surface temperatures (SSTs) from the National Oceanic and Atmospheric Administration (NOAA; Reynolds et al., 2007) are analysed for the detailed case study on 2 July 2016. The SST analysis has a spatial resolution of $0.25^{\circ}$ and a temporal resolution of $1 \mathrm{~d}$. The product uses Advanced Very High Resolution Radiometer (AVHRR) satellite data from the Pathfinder AVHRR SST dataset (Stowe et al., 2002).

5. The Global Precipitation Measurement Integrated Multi-satellitE Retrievals (GPM-IMERG) product from the National Aeronautics and Space Administration (NASA) is used for rainfall evaluation. It uses an algorithm that merges precipitation radar, microwave precipitation estimates, microwave-calibrated infrared, and rain gauge analyses at a spatial resolution of $0.1^{\circ}$ over the latitudinal belt $60^{\circ} \mathrm{N}-60^{\circ} \mathrm{S}$. The product has a time 
resolution of 30 min (Hou et al., 2014; Huffman et al., 2018).

All observational data (satellites and reanalysis data) are colocated with respect to time and space for the comparison with the model results.

\subsection{Modelling}

For the simulations performed in this study, the numerical weather prediction model of the COnsortium for Small-scale MOdelling (COSMO; Baldauf et al., 2011) coupled online with Aerosol and Reactive Trace gases (ART) is used (Vogel et al., 2009). COSMO-ART allows for the treatment of aerosol dynamics, atmospheric chemistry, and the feedback with radiation and cloud microphysics (Vogel et al., 2009; Knote et al., 2011; Bangert et al., 2012; Athanasopoulou et al., 2013). A 1-D plume rise model of biomass burning aerosols and gases in COSMO-ART calculates online the injection height of the biomass pollution plume and the emission strength of gases and particles (Walter et al., 2016). The parameterization scheme uses data obtained from the Global Fire Assimilation System (GFAS v1.2; Kaiser et al., 2012), in particular MODIS satellite data of the fire radiative power. Anthropogenic emission data are taken from the Emission Database for Global Atmospheric Research Hemispheric Transport of Air Pollution version 2 (EDGAR HTAP_v2; Edgar, 2010) for 2010 with a $0.1^{\circ}$ horizontal resolution. In addition, the recently developed gas flaring emission parameterization for SWA by Deetz and Vogel (2016) was used, which is based on a combination of remote sensing observations and physically based combustion equations. Biogenic emissions, sea salt, dimethyl sulfide, and mineral dust are calculated online within the model system. Meteorological initial and boundary conditions are taken from operational global ICOsahedral Non-hydrostatic (ICON) model (Zängl et al., 2015) runs of the German Weather Service (DWD). Initial and boundary conditions for gaseous and particulate compounds are derived from forecasts using the Model for Ozone and Related Chemical Tracers (MOZART; Emmons et al., 2010).

In order to cover a large domain including the fire areas in central Africa and, at the same time, to reach a high horizontal resolution in our area of interest (Gulf of Guinea and SWA), we used the nesting option of COSMO-ART. The modelling domains are presented in Fig. 1. The outer domain $\mathrm{D} 1\left(18^{\circ} \mathrm{W}-26.6^{\circ} \mathrm{E} ; 20^{\circ} \mathrm{S}-24.6^{\circ} \mathrm{N}\right)$, indicated by the small box at the bottom left corner of the figure, covers West Africa and western central Africa as well as the adjacent southeastern Atlantic Ocean. The red rectangle inside this box shows the location of the nested domain $\mathrm{D} 2\left(9^{\circ} \mathrm{W}-1^{\circ} \mathrm{E}\right.$; $3-10.8^{\circ} \mathrm{N}$ ), mostly covering Côte d'Ivoire and Ghana. The colour shading gives the surface height above sea level. D2 is dominated by tropical forests in the south to savanna and grassland vegetation in the north. Simulations are run on D1 with a horizontal grid spacing of $5 \mathrm{~km}$ and 50 verticals levels.

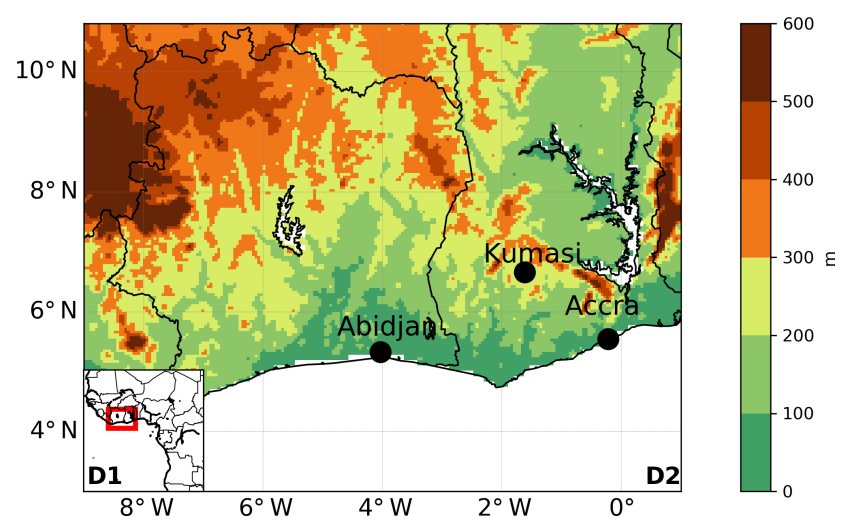

Figure 1. Geographical overview. Model domains D1 (inset) and D2 (main image). The horizontal resolution is $5 \mathrm{~km}$ in the case of $\mathrm{D} 1$ and $2.5 \mathrm{~km}$ in case of D2. The colour shading gives the surface height above sea level over D2. The black dots mark the largest cities of the region: Abidjan, Accra, and Kumasi.

The simulation over D2 is nested into D1 with a horizontal grid spacing of $2.5 \mathrm{~km}$ with 80 verticals levels up to $30 \mathrm{~km}$ (28 levels below $1.5 \mathrm{~km}$ a.s.l.).

The model configuration used in this study is the same as in Deetz et al. (2018). Both domains, D1 and D2, were run with the parametrization for deep convection switched off and using the two-moment microphysics scheme (Seifert and Beheng, 2006). Over D1, the modelled period ranges from 25 June to 31 July 2016 with the meteorological state being re-initialized every day at 00:00 UTC. ICON operational forecasts at $13 \mathrm{~km}$ grid spacing with 90 vertical levels are used as meteorological initial and boundary conditions and MOZART chemistry with a grid mesh of $280 \mathrm{~km} \times 213 \mathrm{~km}$ and 56 vertical levels for the pollutant initial and boundary data. Cloud condensation nuclei are prescribed with a constant aerosol number concentration of $1700 \mathrm{~cm}^{-3}$. The purpose of the D1 simulation is to compare the model output and observations for monthly-mean conditions, i.e., for July 2016, after a $6 \mathrm{~d}$ spin-up.

In addition, we analyse a particular case study on 2-3 July 2016 simulated over D2 using the outputs of D1 for both meteorological and chemical initial and boundary conditions. The period 2-3 July 2016 was chosen because it falls into the post onset phase of the monsoon, characterizing an undisturbed monsoon condition, and is thus favourable for process studies (Knippertz et al., 2017; Deetz et al., 2018). The two-moment microphysics scheme was combined with the prognostic aerosol, accounting for aerosol direct and indirect interactions in this way. The purpose of this run is to perform detailed process studies, in particular with respect to the cloud-induced mixing over the Gulf of Guinea. An artificial tracer experiment is performed to quantify the percentage of mass mixed from the free troposphere into the PBL. We use $\mathrm{CO}$ as an inert tracer and a surrogate for biomass burning emissions. The deposition velocity is set to zero and 
chemistry switched off in order to account only for meteorological atmospheric transport processes. Interactions between gas phase chemistry, aerosol dynamics, and meteorology are neglected. We set a constant profile of $1 \mathrm{ppmv}$ at the height where the maximum concentration of the biomass burning plume is observed (i.e., $2-4 \mathrm{~km}$ ) and 0 below and above that layer. This concentration is held constant at the domain boundaries during integration, while mixing processes can change it in the interior.

\section{Model evaluation}

Figure 2a shows a July 2016 average of the wind speed and streamlines at $925 \mathrm{hPa}$ as simulated by COSMO-ART. Figure $2 \mathrm{~b}$ shows the corresponding figure for the ERA-Interim reanalysis. The wind is southeasterly in the Southern Hemisphere and turns southwesterly along the Guinea Coast after crossing the Equator. This low-level monsoon flow advects relatively cool and moist air from the Gulf of Guinea onto the continent. In July the precipitation maximum is located around $10^{\circ} \mathrm{N}$ (e.g., Janicot et al., 2008), and westerlies penetrate far north into the continent and over the adjacent Atlantic Ocean. Apart from a slightly northward-shifted turning point and more fine-scale detail in the higher-resolved COSMO-ART data, the agreement with ERA-Interim in terms of the overall structure of the low-level flow field is good. However, there are some prominent differences in wind speed. ERA-Interim shows highest wind speeds in the Southern Hemisphere and a slow down towards SWA as well as a clear minimum over central Africa. COSMO-ART simulates a stronger monsoon flow and also significantly higher winds over central Africa. Maxima reach $15 \mathrm{~m} \mathrm{~s}^{-1}$ in both model and reanalysis. COSMO-ART shows a domain average of $6 \mathrm{~m} \mathrm{~s}^{-1}$, which is $1.4 \mathrm{~m} \mathrm{~s}^{-1}$ higher than ERA-Interim.

The wind field at $700 \mathrm{hPa}$ is characterized by a broad easterly flow across most of the considered domain (Fig. 2c and d). A maximum is found over the Sahel known as the African Easterly Jet (AEJ), which typically peaks around $600 \mathrm{hPa}$ (Parker et al., 2005) and is the result of the large meridional temperature gradient at low levels (Cook, 1999; Wu et al., 2009). The AEJ is well represented in COSMOART with a maximum wind speed of $10.4 \mathrm{~m} \mathrm{~s}^{-1}$ as compared to $9.73 \mathrm{~m} \mathrm{~s}^{-1}$ in ERA-Interim. Easterlies are also enhanced near the Equator to the south of an area with weaker flow over the Guinea coast. There are some subtle differences between COSMO-ART and ERA-Interim here, with the former showing a larger northward component over the ocean and slightly stronger winds. COSMO-ART also displays more fine structure in the Southern Hemisphere, where winds are overall weaker. Despite the moderate differences discussed above, we anticipate an overall realistic transport of biomass burning aerosol in the model, i.e., westward away from the hotspots in central Africa out to the Atlantic and then north- ward into SWA with the monsoon flow, if downward mixing occurs.

The simulated total cloud fraction averaged over July 2016 (Fig. 3a) is compared to observations from MODIS (Fig. 3b). SWA is very cloudy in summer with typical values ranging from $70 \%$ to almost $100 \%$ in agreement with a multi-year climatology presented in Hill et al. (2016). The cloud cover is overall adequately represented by COSMOART over land, particularly relative to the poor performance of many coarser-resolution climate models (Hannak et al., 2017). Cloud cover maxima stretch from southwestern Ghana to northeastern Côte d'Ivoire, along the Atakora chain at the border of Ghana and Togo, and over the Guinea Highlands of Liberia and Sierra Leone with overall satisfactory agreement between the two datasets. Towards the Sahel, to the north of $8^{\circ} \mathrm{N}$, cloud fraction decreases in COSMOART but much less so in MODIS, which only shows a prominent minimum over central Côte d'Ivoire. Over the Gulf of Guinea, cloud cover is clearly overestimated by the model, suggesting a potential overestimation of cloud-induced mixing. The two local minima upwind of Abidjan and Accra may be related to coastal upwelling but are hard to verify with MODIS due to the coarser resolution.

Finally, the modelled mixing ratio of surface $\mathrm{CO}$ (Fig. 4a) is evaluated with satellite data from MOPITT for July 2016 (Fig. 4b). A gridded monthly mean of CO from MOPITT is computed using the daily-mean $\mathrm{CO}$ retrieved for the 1000$900 \mathrm{hPa}$ layer. Some areas have too frequent cloud contamination and therefore do not allow for the computation of a representative monthly mean (white shading in Fig. 4b). Overall the spatial patterns of $\mathrm{CO}$ concentration are captured by the model with some discrepancies. Over central Africa widespread burning is evident with a larger magnitude and spatial extent in the model as compared to MOPITT. From there, a plume of enhanced concentrations stretches northwestward in both datasets, but again values in COSMO-ART are somewhat larger and therefore reach more remote parts of the Atlantic Ocean. This also supports a potential overestimation of the import of pollution from central Africa into SWA in the model. In addition, COSMO-ART simulates marked pollution plumes over Nigeria associated with Lagos, the oil fields in the Niger Delta (flaring activities), and the Sahelian city of Kano, which are hard to verify with MOPITT due to cloud contamination. However, emissions from Kano, where clouds are less frequent than in the south, are likely overestimated. Emissions from other large cities (e.g., Accra, Kumasi, Abidjan) in contrast appear relatively weak in COSMO-ART. This may be at least partly due to uncertainties in standard emission inventories (Liousse et al., 2014). Despite some overall discrepancies, we argue that the two fields are similar enough to draw conclusions on the importance of cloud-mixing process in the model, particularly because the fields are relatively similar over the ocean. 
(a) COSMO-ART $925 \mathrm{hPa}$

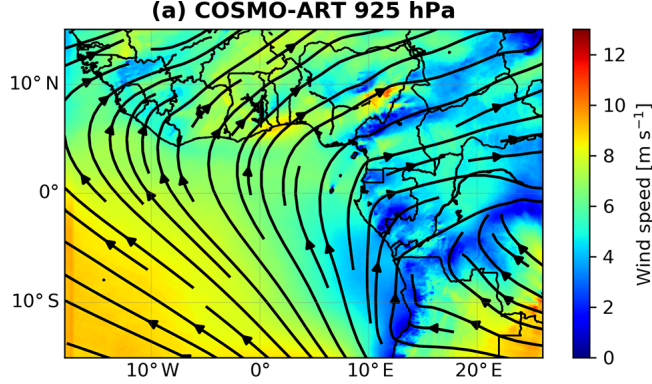

(c) COSMO-ART $700 \mathrm{hPa}$

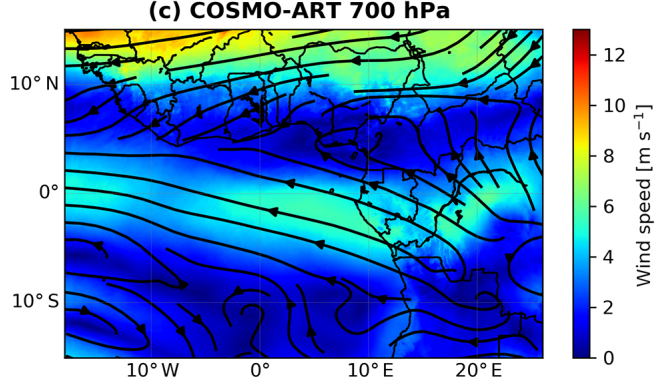

(b) ERA-Interim $925 \mathrm{hPa}$

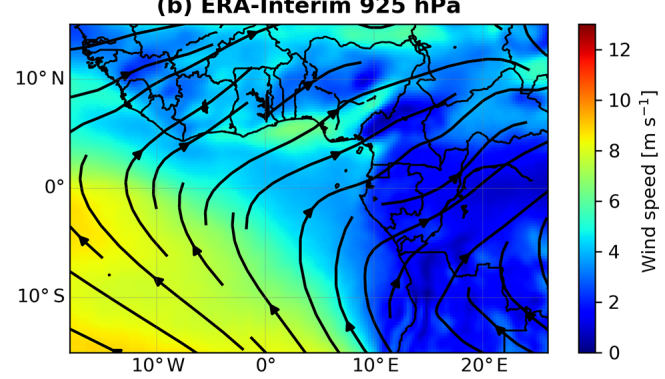

(d) ERA-Interim $700 \mathrm{hPa}$

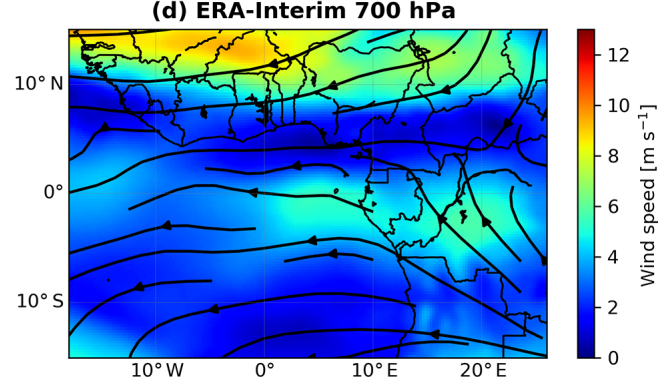

Figure 2. Average wind speed (colour shading) and streamlines at $925 \mathrm{hPa}(\mathbf{a}, \mathbf{b})$ and $700 \mathrm{hPa}(\mathbf{c}, \mathbf{d})$ simulated with COSMO-ART (a, c) and in the ERA-Interim reanalysis $(\mathbf{b}, \mathbf{d})$ for July 2016. Note the different scales in top and bottom panels.

(a) COSMO-ART

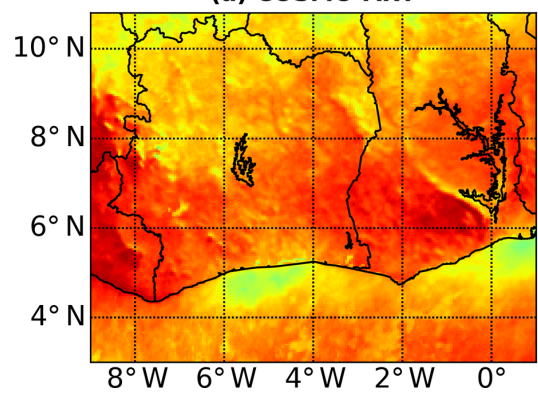

(b) MODIS

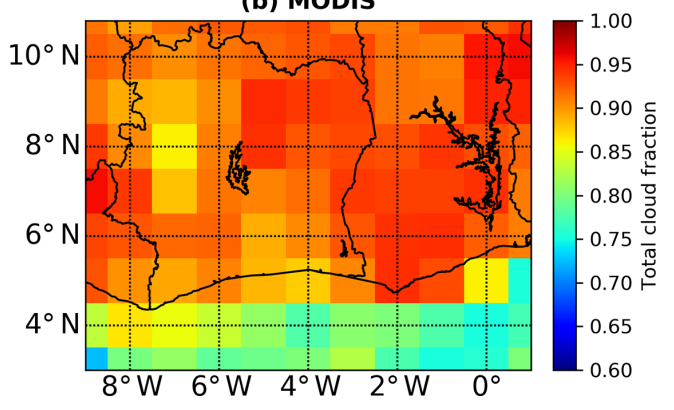

Figure 3. Monthly-mean total cloud fraction for July 2016 over domain D2 as simulated with COSMO-ART (a) and observed by MODIS (b).

\section{A case study}

In Sect. 3 we present simulated monthly-mean conditions. We will now focus on a case study for 2 July 2016 to illustrate the impact of meteorology on the spatial and temporal distribution of CO. We will especially focus on the role of convective clouds on the vertical distribution of CO.

\subsection{Simulated temperature distribution}

The spatial distribution of simulated $2 \mathrm{~m}$ temperature at 12:00 UTC on 2 July 2016 is displayed in Fig. 5. At this time of day the temperature is already higher over land than over the ocean. Local temperature maxima are located over cities such as Abidjan and Accra. High temperatures are also simulated in the central part of Ghana near Lake Volta. Modelled temperatures over the Gulf of Guinea are between 26 and $28^{\circ} \mathrm{C}$ in agreement with observed SSTs shown in Knippertz et al. (2017). In Fig. 5 there are clear indications of cold pools related to convective cells developing over the Gulf over Guinea and the adjacent land areas, particularly over southern Côte d'Ivoire (see Fig. 6c for precipitation). The hourly analysis of the temperature field (not shown) shows cold pools first appearing around 07:00 UTC and persisting during the whole day. They are connected to downward motion starting at and above cloud base, bringing air and its constituents from aloft into the PBL.

\subsection{Spatial distribution of clouds and rainfall}

Satellite-retrieved images from EUMETSAT on 2 July 2016 show widespread clouds over SWA and the adjacent ocean, with convective cells located over the Gulf of Guinea south of Côte d'Ivoire at 12:00 UTC (Fig. 6b). They produce rain rates of several millimetres per hour $\left(\mathrm{mm} \mathrm{h}^{-1}\right)$ in the course of the afternoon according to GPM-IMERG (Fig. 6d). The cells over the ocean developed near the border between Côte d'Ivoire and Ghana in the morning hours and propagated 

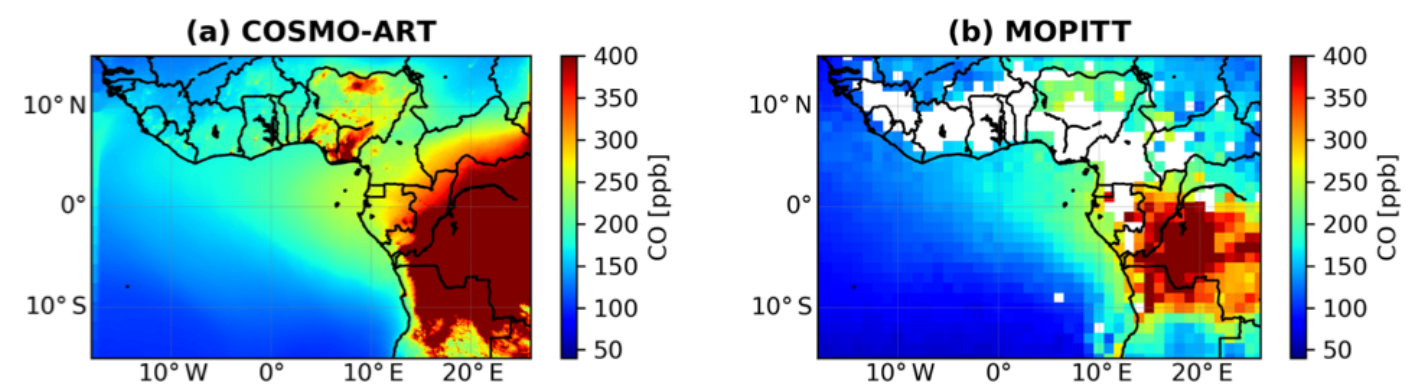

Figure 4. Monthly-mean surface CO concentrations for July 2016 as simulated by COSMO-ART (a) and as observed by MOPITT (b).

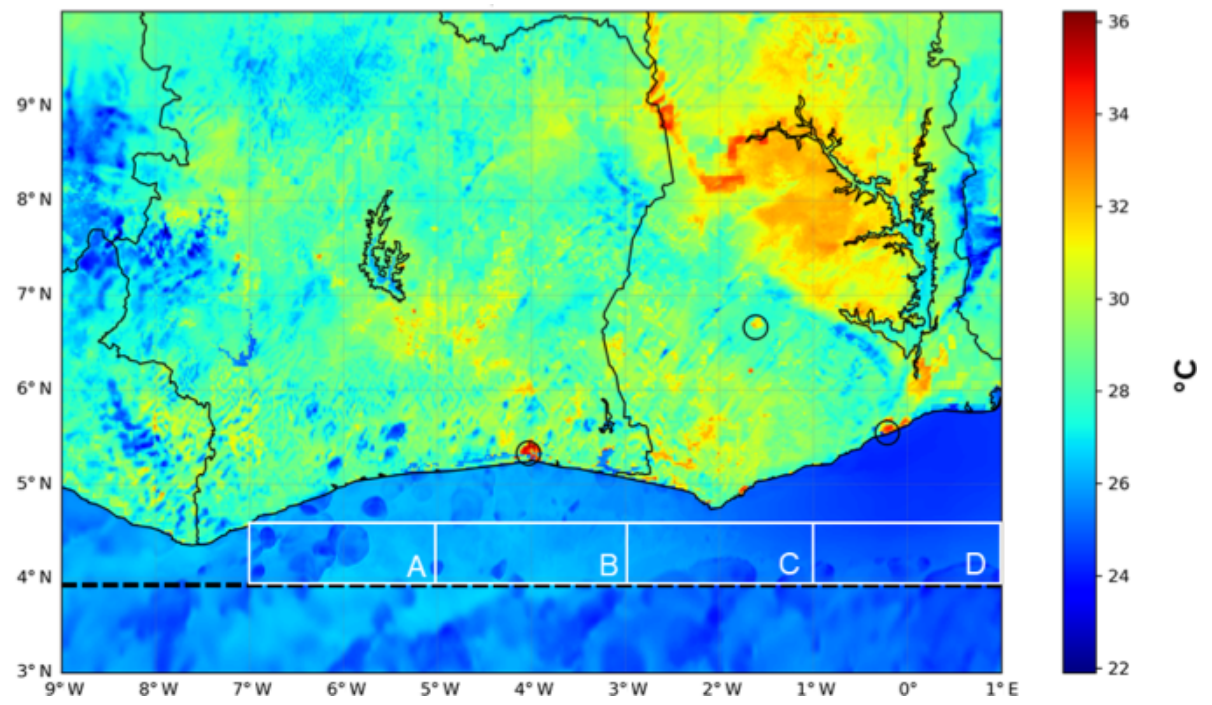

Figure 5. $2 \mathrm{~m}$ temperature as simulated by COSMOS-ART over domain D2 (see Fig. 1) on 2 July 2016 at 12:00 UTC. Note the small-scale cold-pool signatures over the ocean. The circles mark the urban heat islands of Abidjan, Kumasi, and Accra. The position of the zonal cross section in Fig. 8 is marked with a dashed line. Different subdomains are defined between 4 and $4.7^{\circ} \mathrm{N}$ that will be used for the tracer experiments discussed in Sect. 5 (see Fig. 11): $7-5^{\circ} \mathrm{W}(\mathrm{A}), 5-3^{\circ} \mathrm{W}(\mathrm{B}), 3-1^{\circ} \mathrm{W}(\mathrm{C})$, and $1^{\circ} \mathrm{W}-1^{\circ} \mathrm{E}(\mathrm{D})$.

slowly westward in the course of the day (not shown). They formed despite anomalously cold coastal waters but may have benefitted from substantially warmer SSTs nearer the Equator (see Fig. 3 in Knippertz et al., 2017). Mostly moderate precipitation is also observed over land, in central Ghana, around Kumasi as well as along the borders between Cote d'Ivoire with Liberia, Guinea, and Mali.

Corresponding total cloud cover and precipitation as simulated by COSMO-ART are shown in Fig. 6a and c. In the model the whole area is dominated by clouds (Fig. 6a) with moderate gaps around Lake Volta and over the ocean upwind of Ghana and Côte d'Ivoire. There is reasonable qualitative agreement between the model and observations (Fig. 6b), but the differences in cloud optical thickness evident from the satellite image make a detailed comparison somewhat difficult. With respect to precipitation, COSMO-ART shows substantially more fine structure than GPM-IMERG. Many localized showers are evident over Côte d'Ivoire and neighbouring countries with higher intensities over the hilly ter- rain in Liberia and along the land-sea breeze convergence parallel to the coast. Larger cells form in the model over the hills surrounding Lake Volta. The largest and most intense convective systems are simulated over the ocean with a pronounced north-south elongation along the southwesterly monsoon flow. These were persistent throughout the day (not shown). Despite the differences in resolution, there is overall good qualitative agreement between model and observations, in particular with respect to the maxima over central Ghana and Liberia. Convection in the north is underestimated and convection over the ocean is overestimated by COSMOART in agreement with the cloud biases evident from Fig. 3. The latter further confirms that cloud-induced mixing may be somewhat overestimated by COSMO in this specific case, allowing only a rather qualitative assessment.

\subsection{Simulated and observed spatial distribution of CO}

Figure 7 presents the simulated spatial distribution of the $\mathrm{CO}$ concentration for 2 July 2016, 12:00 UTC, at about 500 and 
(a) COSMO-ART

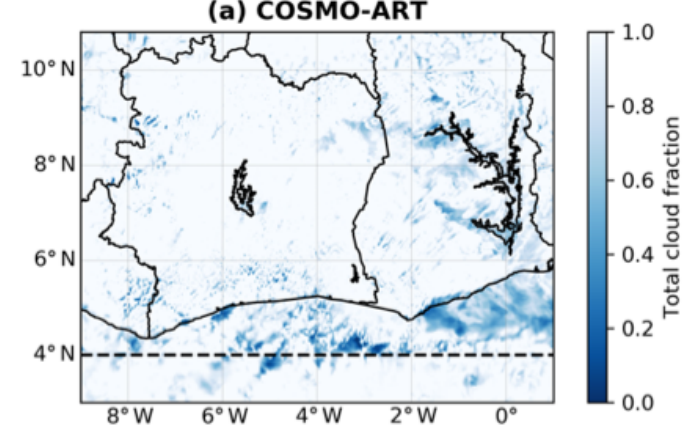

(c) COSMO-ART

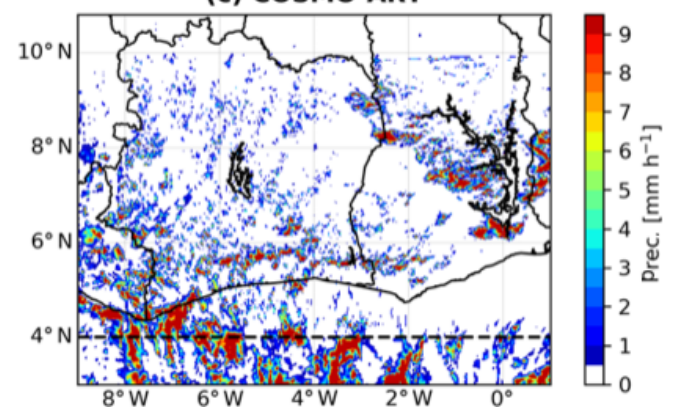

(b) SEVIRI

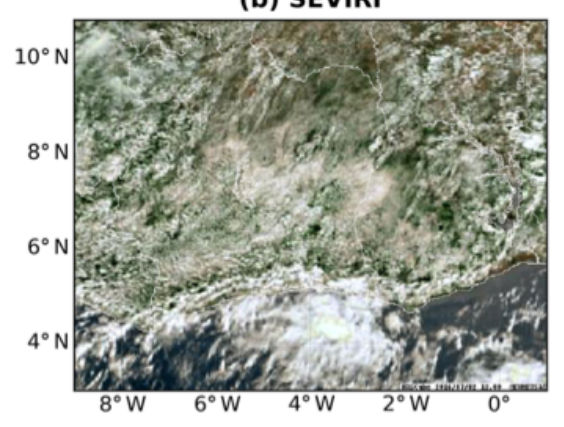

(d) GPM

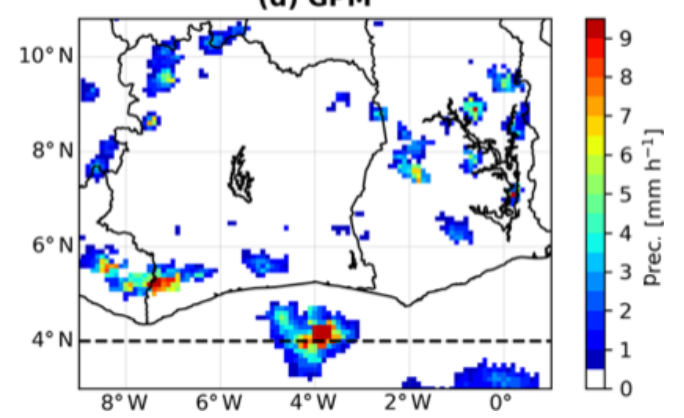

Figure 6. Spatial distribution of clouds and rainfall over domain D2 (see Fig. 1) on 2 July 2016. (a) Total cloud fraction simulated by COSMO-ART at 12:00 UTC. (b) Spinning Enhanced Visible and InfraRed Imager (SEVIRI) cloud visible image from EUMETSAT at 12:00 UTC (from http://nascube.univ-lille1.fr, last access: 17 May 2019). (c) Precipitation rate simulated by COSMO-ART at 18:00 UTC and (d) corresponding fields from the GPM-IMERG rainfall estimates. The position of the zonal cross section in Fig. 8 is marked with dashed lines.

$2000 \mathrm{~m}$ above the ground over the domains D1 (Fig. 7a and b) and D2 (Fig. 7c and d). At $500 \mathrm{~m}$ (Fig. 7a) there is a stark concentration difference between land and ocean with thick pollution plumes over the biomass burning areas in central Africa (Barbosa et al., 1999; Mari et al., 2008; Zuidema et al., 2016) and over Nigeria. The urban plumes from coastal cities such as Abidjan, Cotonou, Lomé, and Lagos are also visible. These results come from the high anthropogenic emissions used in our study, which have maxima over Nigeria and the big cities along the coast. The simulated hourly $\mathrm{CO}$ concentrations (not shown here) reveal that there is a northeastward transport of CO from the local sources in the PBL with the southwesterly monsoon flow (Knippertz et al., 2017; Deroubaix et al., 2018). However, Flamant et al. (2018a) also showed that parts of the urban pollution can recirculate to the near-coastal waters after being mixed into the midlevel easterly or sometimes northeasterly flow. Significantly lower but still considerable $\mathrm{CO}$ concentrations are simulated in the marine PBL over the entire eastern tropical Atlantic including the Gulf of Guinea. There is a local enhancement next to the coast stretching from Cameroon to Côte d'Ivoire. At this height level, $\mathrm{CO}$ is transported with the southwesterly monsoon winds from the ocean toward SWA coastal cities (see Fig. 2). Compared to the monthly-mean concentration of CO (Fig. 4), 2 July was characterized by elevated pollution levels, especially over Nigeria. Concentrations over the nested domain D2 at $500 \mathrm{~m}$ (Fig. 7c) are moderated with traces of higher $\mathrm{CO}$ concentrations over the Gulf of Guinea, some smaller elongated plumes (e.g., from Abidjan and Accra), and more elevated levels downstream of Lake Volta. As concentrations above ground level are shown in Fig. 7c, the elevated values over the Atakora chain at the border of Ghana with Togo are at least party related to the fact that higher ground is closer in the vertical to the main midlevel pollution plume from central Africa.

Aloft at approximately $2000 \mathrm{~m}$ (Fig. 7b), the CO distribution is fundamentally different. Maximum CO concentrations with values of about $400 \mathrm{ppbv}$ are found over the eastern Atlantic Ocean, downstream of the main burning areas in southern and central Africa. High concentrations stretch far into SWA (e.g., into Burkina Faso, Mali, and Niger), even in areas where $500 \mathrm{~m}$ concentrations are not that high, e.g. over Côte d'Ivoire (Fig. 7a). This clearly suggests a relationship to long-range transport of biomass burning plumes and is further corroborated by much reduced values in a simulation where biomass burning emissions are suppressed (not shown). The elevated concentrations at $500 \mathrm{~m}$ over the ocean to the west and north of the main plume at $2000 \mathrm{~m}$ (i.e. over the equatorial Atlantic Ocean near $15^{\circ} \mathrm{W}$ and arching into the Gulf of Guinea) suggest downward mixing into the PBL from aloft, which is further elucidated in the following paragraph. Subsidence within the high-pressure system west of 
(a) CO at $500 \mathrm{~m}$ at 12:00 UTC

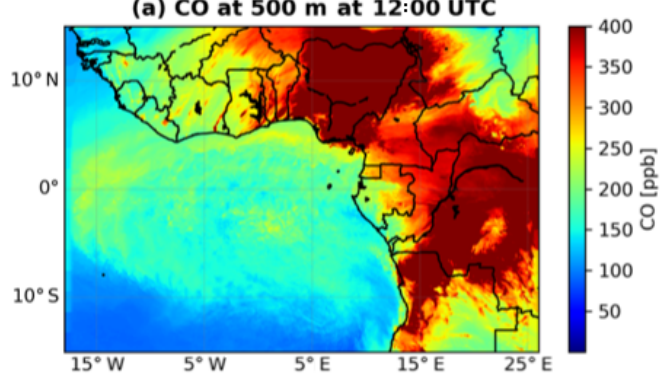

(c) CO at $500 \mathrm{~m}$ at 12:00 UTC

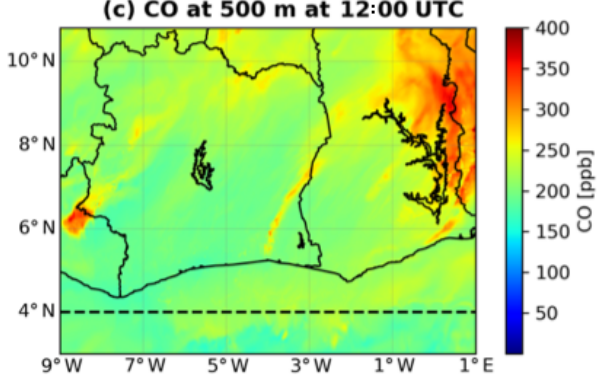

(b) CO at $2000 \mathrm{~m}$ at 12:00 UTC

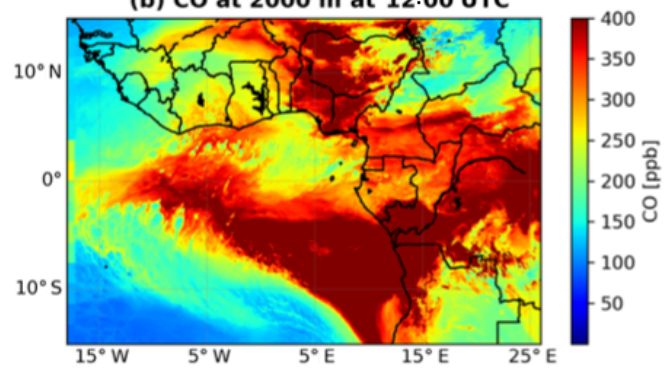

(d) CO at $2000 \mathrm{~m}$ at 12:00 UTC

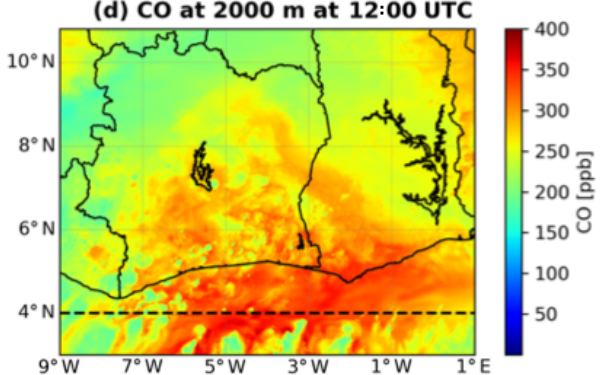

Figure 7. CO concentrations on 2 July 2016 at 12:00 UTC as simulated by COSMO-ART at (a) ca. $500 \mathrm{~m}$ and (b) ca. $2000 \mathrm{~m}$ a.g.1. over D1 and at (c) ca. $500 \mathrm{~m}$ and (d) ca. $2000 \mathrm{~m}$ over D2.

the African continent may also support the downward transport of CO into the PBL (Zuidema et al., 2016). Zooming in on domain D2 (Fig. 7d), concentrations at $2000 \mathrm{~m}$ are generally much higher than at $500 \mathrm{~m}$ (Fig. 7c), in particular over the coastal zone. Strikingly some marked "holes" are evident that correspond to areas of convective cells and associated cold pools (see Figs. 5 and 6c), suggesting that in these areas clouds support downward mixing.

To further investigate this hypothesis, vertical distributions of $\mathrm{CO}$ concentrations and cloud liquid water content from model output are considered (Fig. 8). High CO concentrations are simulated over most of the Gulf of Guinea but levels are generally higher between 10 and $0^{\circ} \mathrm{W}$ (upwind of Cote d'Ivoire and Ghana) than between 0 to $5^{\circ} \mathrm{E}$ (Fig. 7b) and we will therefore concentrate on this region.

Figure 8a and b show zonal cross sections of $\mathrm{CO}$ over the Gulf of Guinea at $4^{\circ} \mathrm{N}$ (i.e., close to the coastal cities of SWA) over D2 on 2 July 2016 at 12:00 and 18:00 UTC, respectively. There is a clear band of high $\mathrm{CO}$ concentrations of up to $400 \mathrm{ppbv}$, mostly between 1 and $3.5 \mathrm{~km}$ over $\mathrm{D} 2$, which is the signature of the long-range transport of the biomass burning plume from central Africa (Mari et al., 2008; Zuidema et al., 2016), possibly affected by largerscale subsidence. Several stripes of low concentration are simulated and these structures become more pronounced at 18:00 UTC (Fig. 8b). They are related to simulated (and also observed) convective clouds (Fig. 6) that transport $\mathrm{CO}$ into the PBL from above. Analysing the simulated diurnal cycle (not shown), we found that over the ocean clouds appear after 07:00 UTC and are persistent throughout the day, while $\mathrm{CO}$ becomes increasingly visible in the PBL and eventually reaches the surface. Concentrations below $1 \mathrm{~km}$ can reach up to $60 \%$ of the maximum located at midlevel height due to downward mixing.

Figure $8 \mathrm{c}$ and $\mathrm{d}$ show meridional-vertical cross sections of, respectively, $\mathrm{CO}$ concentration and specific cloud liquid water content along $6^{\circ} \mathrm{W}$, close to where convective activity is seen in Fig. 8a. Areas of high cloud liquid water are colocated with minima in $\mathrm{CO}$, supporting the idea of cloudinduced transport and mixing. The most prominent of such areas is located around $4.3^{\circ} \mathrm{N}$, where significant amounts of cloud water stretch from below $500 \mathrm{~m}$ to almost the top of the biomass burning plume, leading to substantial erosion.

For comparison, we also analyse meridional cross sections of $\mathrm{CO}$ corresponding to Fig. $8 \mathrm{c}$ but at longitudes of $4^{\circ} \mathrm{W}$ and $1^{\circ} \mathrm{E}$ over domain D2. At $4^{\circ} \mathrm{W}$ (Fig. 8e) there are no pronounced gaps in the pollution plume, suggesting less convective mixing at this time than at $6^{\circ} \mathrm{W}$, but concentrations at low levels are not much different. There is even a slight increase northwards that may come from turbulent mixing or zonal advection into the section. In contrast to that, the cross section at $1^{\circ} \mathrm{E}$ (Fig. 8f), which corresponds to the ocean offshore of the border of Ghana with Togo, shows a much weaker biomass burning plume in agreement with Fig. 7b. This appears to be the result of the bulk of the plume travelling westward over the ocean before turning northward into SWA. Also here, a slow decent of the lower boundary of the plume is visible. This may come from large-scale subsidence associated with the southern branch of the Hadley cell and/or from turbulent mixing.

Finally, it is also interesting to place the mixing near SWA into the larger regional context. Meridional cross sections 

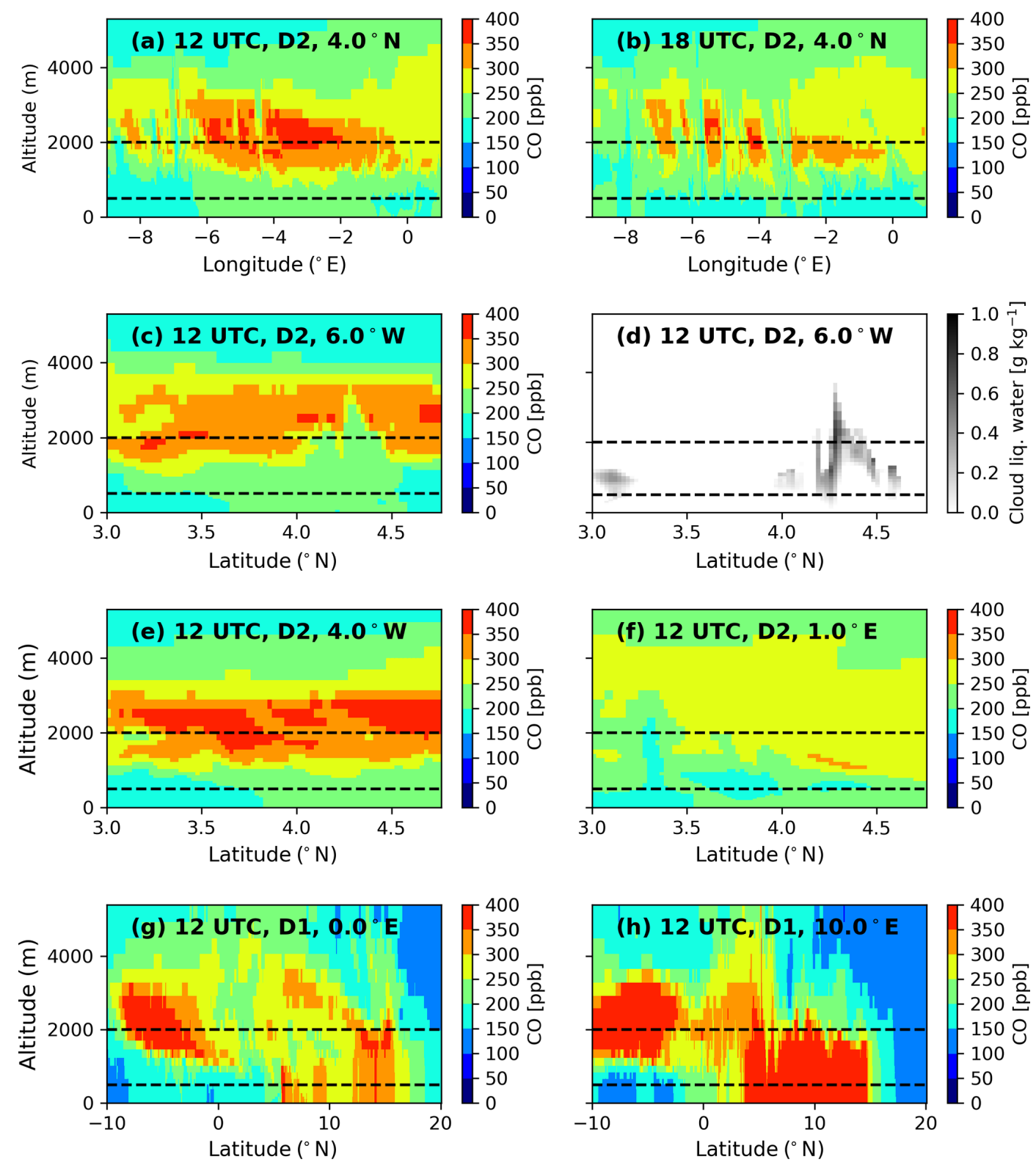

Figure 8. Vertical cross sections of CO concentration and cloud liquid water content as simulated by COSMO-ART over domains D1 and D2 (see Fig. 1). Zonal-vertical cross sections at $4^{\circ} \mathrm{N}$ of the CO concentration at (a) 12:00 UTC and (b) 18:00 UTC on 2 July 2016 for domain D2. (c) Meridional-vertical cross section at 12:00 UTC at $6^{\circ} \mathrm{W}$ and (d) corresponding cloud liquid water content, both for domain D2. (e) and (f). Same as (c) but for $4^{\circ} \mathrm{W}$ and $1^{\circ} \mathrm{E}$, respectively. (g) and (h) Meridional-vertical cross sections over D1 at 0 and $10^{\circ}$ E, respectively. Heights are given in altitude above ground level and the levels shown in Fig. 7 are marked by dashed lines in all panels. The arrows in (g) and (h) indicate the coastline.

along 0 and $10^{\circ} \mathrm{E}$, but reaching from $10^{\circ} \mathrm{S}$ to $20^{\circ} \mathrm{N}$, illustrate the full complexity of the plume evolution. At $0^{\circ} \mathrm{E}$ (Fig. 8g) there is a distinct biomass burning plume centred at $5^{\circ} \mathrm{S}$. The skewed shape of this feature suggests a relatively fast northward transport around $1000 \mathrm{~m}$ a.g.l. Individual mixing events are evident (green spikes underneath the main plume in Fig. 8g). North of the coast (marked by an arrow in Fig. 8g) there is a complicated vertical structure with local near-surface emissions, overhead advection, and verti- cal mixing to various degrees, particularly during the daytime shown here. Farther to the east at $10^{\circ} \mathrm{E}$ (Fig. 8h) the situation bears some similarities, but the local emissions from Nigeria appear to play a larger role over land, and the lofted biomass burning plume is more prominent over the immediate coast (see also Fig. 7b). 


\section{Downward cloud venting}

The discussion in Sect. 4 suggests that long-rangetransported biomass burning aerosol from central Africa can be mixed into the PBL over the Gulf of Guinea in association with convective clouds. We will refer to this process as downward cloud venting in the following in contrast to the more classical upward cloud venting (e.g., Cotton et al., 1995).

In general, processes that can support the transport of biomass burning aerosols from free-tropospheric layers into the PBL include (i) large-scale subsidence and thus vertical advection (Katoshevski et al., 1999), (ii) turbulent mixing through the PBL top, and (iii) vertical transport associated with convective clouds. With respect to point (i) we can state that the cross sections in Fig. 8 do not show clear indications of a systematic sinking of the biomass burning plume, suggesting that for the situation presented in Sect. 4 synopticscale subsidence is not a leading factor.

To investigate the relative importance of processes (ii) and (iii), we designed an idealized tracer experiment. For the simulations starting at 2 July 2016 at 00:00 UTC, initial profiles of a tracer were prescribed within the D1 and D2 domains. The idealized tracer has a concentration of 1 ppmv between 2 and $4 \mathrm{~km}$ and is zero elsewhere. Chemical reactions as well as dry deposition are neglected in order to isolate effects of transport. At the lateral boundaries the tracer concentrations were held constant at the initial profile such that only mixing within the domain can change tracer concentrations. Two types of simulations were done: one with and one without turbulent diffusion of the tracer. The idea behind this is to separate this effect from that of downward cloud venting. The simulations were carried out for a period of $2 \mathrm{~d}$ (2-3 July 2016).

For the larger domain D1, Fig. 9 shows the percentage of tracer mass located between 2 and $4 \mathrm{~km}$, between 1 and $\mathrm{km}$, and below $1 \mathrm{~km}$; the latter two with and without turbulent tracer diffusion. As the PBL is usually quite shallow over the ocean (as indicated, for example, by the low cloud base in Fig. 8d), the lowest layer should in most cases comprise the entire PBL and possibly also the lower part of the free troposphere with some variations in space and time. All values are averaged between $9^{\circ} \mathrm{W}$ and $1^{\circ} \mathrm{E}$, and the different panels show time evolutions along different latitude circles.

Over the open ocean at 5 and $0^{\circ} \mathrm{S}$ (Fig. 9a, b), where mostly shallow cumuli are present, the concentration in the layer between 2 and $4 \mathrm{~km}$ stays fairly high over the $2 \mathrm{~d}$ period with well over $80 \%$ still present at the end of the simulation. The increase in the tracer mass in the intermediate layer from 1 to $2 \mathrm{~km}$ starts almost immediately after the beginning of the simulation and reaches a plateau well above $20 \%$ during day 2 . This indicates that this increase cannot solely be the result of vertical mixing near the shown latitude circle but must also be related to horizontal transport of tracer that was mixed downwards upstream. The final tracer amount is almost independent of whether turbulent diffusion is consid- ered or not, indicating the importance of downward cloud venting (compare dashed and solid red lines in Fig. 9a and b). The tracer reaches the layer below $1 \mathrm{~km}$ at the end of the second day parallel to a marked increase in the layer above. The tracer mass then slowly increases to reach final values ranging around $15 \%$. Here, the vertical mixing clearly is a combination of turbulent diffusion and cloud-induced mixing with the former contributing on the order of one-quarter to one-third. It is interesting to note that the southernmost section has a higher percentage of cloud-induced mixing than that over the equatorial cold tongue. Below we will show evidence that the higher SST in the former region likely supports cloud formation and associated mixing.

Over the Gulf of Guinea between 4 and $4.7^{\circ} \mathrm{N}$ (i.e., the latitude range used for Fig. 10) there is a more pronounced decrease in the tracer mass in the layer between 2 and $4 \mathrm{~km}$ down to about $65 \%$ after $2 \mathrm{~d}$ (Fig. 9c). Consistently, the $1-$ $2 \mathrm{~km}$ layer gains more tracer mass and exceeds $30 \%$ on the second day with a more continuous rise than farther south (Fig. 9a and b). Turbulent diffusion appears to play a more important role here, but the overall contribution is still fairly small. The increase in mass below $1 \mathrm{~km}$, however, does not match these differences, reaching values similar to that over the open tropical Atlantic but with a similar contribution from cloud-induced mixing of about $60 \%$. This result illustrates the complicated configuration of differential advection at different height levels combined with spatially differing vertical transport.

To investigate the aspect of SST influence further, Fig. 10 shows the final mixing state in the layer below $1 \mathrm{~km}$ after $2 \mathrm{~d}$ of integration, i.e., the right-hand-side intercept of the black curves in Fig. 9 but for steps of $1^{\circ}$ latitude. Plotted against SSTs for the same longitudinal range, a close correspondence is evident in the Southern Hemisphere. Both mixing and SSTs have a marked maximum around $6-7^{\circ} \mathrm{S}$ followed by a common minimum around $2^{\circ} \mathrm{S}$. To the north, SSTs increase to levels even higher than in the Southern Hemisphere but the tracer mass increases only little. One likely reason for this is the smaller tracer concentrations aloft as evident from Fig. 9c. Another factor may be the flow of near-surface air over the cooler equatorial water, leading to a decrease in buoyancy. It is also possible that enhanced shallow subsidence closer to the coast (see Fig. 8f) helps suppress vertical mixing into the PBL.

Finally over land, i.e., between 5 and $10^{\circ} \mathrm{N}$, the vertical exchange maximizes leading to a reduction in the $2-4 \mathrm{~km}$ layer down to almost $50 \%$ (Fig. 9d). Consistently, tracer mass in the intermediate layer increases more strongly up to well over $44 \%$, while tracer mass below $1 \mathrm{~km}$ reaches $23 \%$. A clear diurnal cycle is evident, particularly in the lower layer, with vertical mixing mostly occurring in the early afternoon when the PBL is deepest. The suppressing of turbulent diffusion reduces the tracer mass by $20 \%$ with some evidence of a diurnal cycle in the differences evident from Fig. 9d. As expected, dry mixing is more important in the 

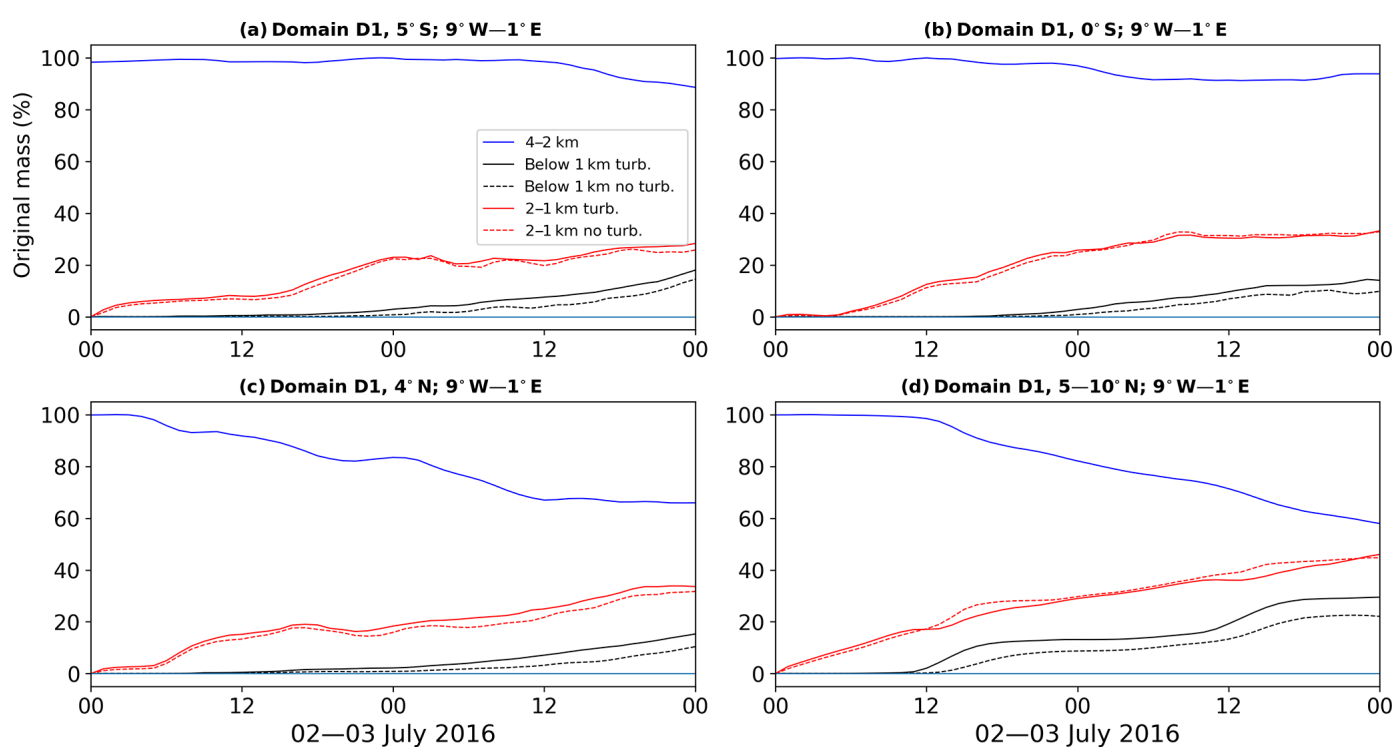

Figure 9. Time evolution of the idealized tracer experiment on 2 and 3 July 2016 over domain D1. Shown are changes in original mass in percent (\%) between 2 and $4 \mathrm{~km}$ (blue), between 1 and $2 \mathrm{~km}$ (red), and below $1 \mathrm{~km}$ (black). For the latter, results including turbulent diffusion are shown by the solid lines and those without by the dashed lines. Fields are averaged from $9^{\circ} \mathrm{W}-1^{\circ} \mathrm{E}$ along (a) $5^{\circ} \mathrm{S}$ (southeastern Atlantic), (b) $0^{\circ}$ (equatorial cold tongue), (c) $4-4.7^{\circ} \mathrm{N}$ (Gulf of Guinea), and (d) $5-10^{\circ} \mathrm{N}$ (inland SWA).

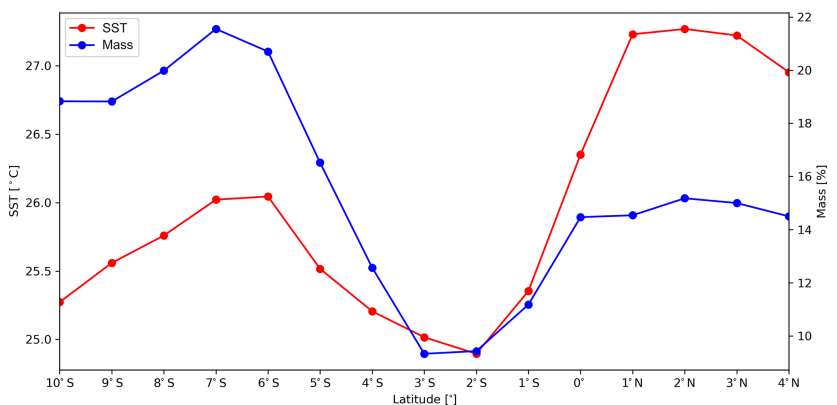

Figure 10. Relationship between sea surface temperatures (SST) and vertical mixing of CO. CO masses in percent (\%) (in blue) correspond to the values for the below $1 \mathrm{~km}$ layer at the end of the time window shown in Fig. 11 but for steps of $1^{\circ}$ latitude. SSTs (in red) are from the Advanced Very High-Resolution Radiometer (AVHRR) and were averaged in the same way as the tracer concentration field.

early afternoon, while cloud-induced mixing peaks later. The important role of clouds in vertical mixing over land is consistent with the large cloud cover shown in Fig. 3. The diurnal cycle is also evident at $1-2 \mathrm{~km}$, where switching off turbulent diffusion leads to a net increase in this layer during the afternoon.

Figure 11 shows results analogous to Fig. 9 but for the model domain D2 and for the areas A-D indicated in Fig. 5. Their latitudinal extent corresponds to Fig. 9c, but the longitudinal extent varies between the different panels. Taken together, the four panels of Fig. 11 stretch from $7^{\circ} \mathrm{W}$ to $1^{\circ} \mathrm{E}$, while Fig. 9c stretches from $9^{\circ} \mathrm{W}$ to $1^{\circ} \mathrm{E}$. Zooming down into such small areas illustrates the impact of short-lived intense local mixing events. While all four subregions show a marked decline in tracer mass in the $2-4 \mathrm{~km}$ layer (blue lines), the evolution is sometimes bumpy and final values range from $41 \%$ in Fig. 11a to about $74 \%$ in Fig. 11c and d. Mixing into the layer immediately below the biomass burning plume (i.e., $1-2 \mathrm{~km}$, red lines) begins a few hours after the start of the simulations with even a transient reduction in some areas, mostly during morning hours. It is possible that the diurnal cycle in monsoon flow and cloudiness over the near landmass contributes to such fluctuations. Some correspondence is seen between "loss" events in the upper-layer and "gain" events in the middle layer, but the connection is not always clear cut, indicating effects of horizontal transport and possibly also mixing upwards from the main aerosol layer. As the $1-2 \mathrm{~km}$ layer is above the PBL in most cases, it is no surprise that switching off turbulent diffusion has very little affect, apart from the easternmost domain where clouds appear to be rather inactive (compare red dashed and solid lines in Fig. 11).

Finally in the layer below $1 \mathrm{~km}$ tracer concentrations are fairly low throughout most of the period in all four subregions. At the end of 2 July moderate increases are seen in the two westernmost domains. These appear to be related to the showers discussed in the context of Figs. 5-8 in the previous section. In the afternoon and evening hours of 3 July a more marked mixing event occurs in the two western domains with concentrations peaking around 18:00 UTC. Reflections of these events can be seen in the upper layers as well. Turbulent diffusion practically plays no role in the mass increase in the lower layer. The event on 3 July contributes 

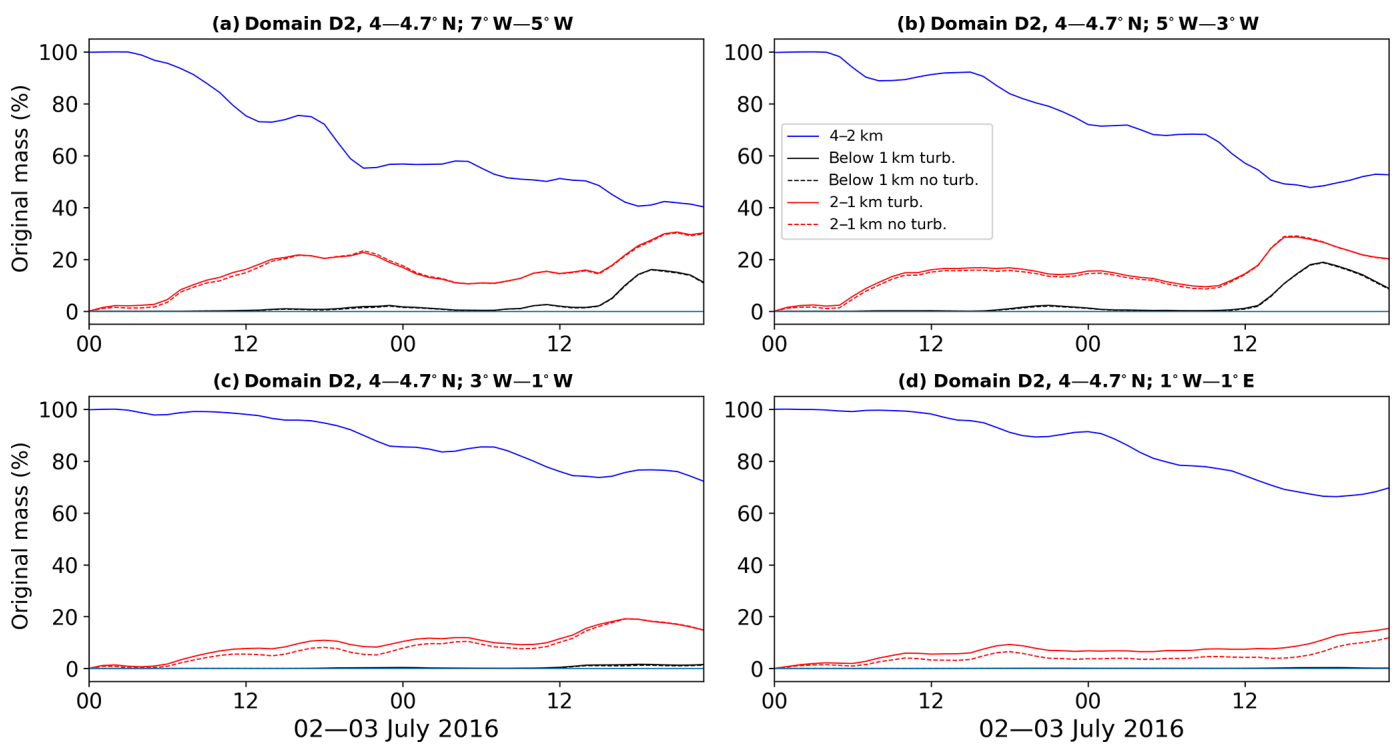

Figure 11. Time evolution of the idealized tracer experiment on 2 and 3 July 2016 over domain D2. Shown are changes in original mass in percent (\%) between 2 and $4 \mathrm{~km}$ (blue), between 1 and $2 \mathrm{~km}$ (red), and below $1 \mathrm{~km}$ (black). For the latter two, results including turbulent diffusion are shown by the solid lines and those without by the dashed lines. Fields are averaged from 4 to $4.7^{\circ} \mathrm{N}$ along $(\mathrm{A}) 7-5^{\circ} \mathrm{W}$, (B) $5-3^{\circ} \mathrm{W},(\mathrm{C}) 3-1^{\circ} \mathrm{W}$, and (D) $1^{\circ} \mathrm{W}-1^{\circ} \mathrm{E}$.

most to the large-scale increase seen in Fig. 9c. This discussion illustrates the influence of localized intense mixing events on tracer concentrations in the PBL, which will largely be missed out by models that parameterize moist convection.

\section{Summary and conclusions}

Recent observational and modelling work has revealed significant concentrations of biomass burning aerosol reaching SWA in the PBL and contributing to a deterioration of air quality there (Brito et al., 2018; Menut et al., 2018; Haslett et al., 2019). It has been suggested that this plume stems from the extensive fires in central Africa during the WAM season. Here we investigated potential transport pathways of the aerosol. While previous studies discussed subsidence to the west of the African continent to be an important mechanism, here we identify - to the best of our knowledge - for the first time that downward cloud venting is one of the processes by which biomass burning aerosol from middle tropospheric layers is mixed into the PBL over the Gulf of Guinea.

This study heavily relied on high-resolution simulations using the COSMO-ART model for July 2016. COSMO-ART enables us to simulate both meteorological fields and $\mathrm{CO}$ distributions over a domain including SWA, central Africa, and the adjacent tropical Atlantic. The simulated wind speed and direction are broadly in agreement with the ERA-Interim reanalysis, although COSMO revealed a somewhat stronger midlevel export from central Africa and faster monsoon flow. Regarding cloud cover, COSMO-ART reproduces areas of maximum and minimum clouds over SWA but overestimates

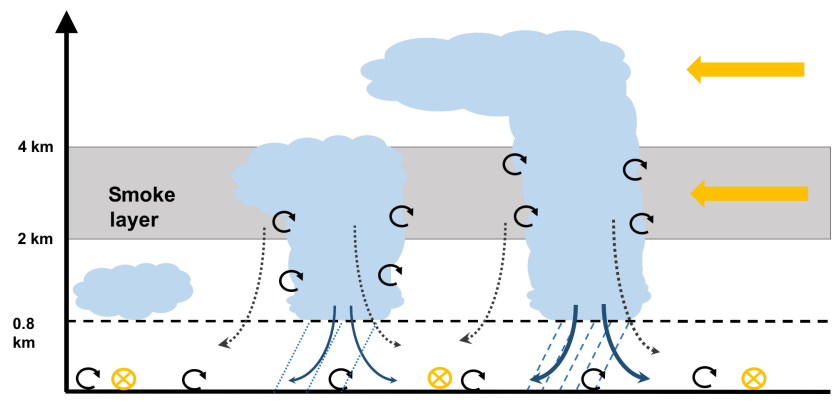

Figure 12. Sketch of the vertical exchange processes that transport aerosol from the central African smoke layer into the PBL over the tropical Atlantic. Shown is an instantaneous ensemble of different cloud types with different vertical extents over the equatorial Atlantic. Blue solid (black stippled) arrows indicate downdraughts from below cloud base (cloud edges) of different strengths. Easterly flow at midlevels is indicated by yellow arrows, while the southerly monsoon flow at low levels is marked by yellow circles with crosses. Turbulent diffusion is indicated by black swirls.

it over the Gulf of Guinea. The spatial distribution of $\mathrm{CO}$ is used as a tracer to detect the biomass burning plume. Compared to observations, the simulated $\mathrm{CO}$ concentration captures the main spatial patterns, but the central African biomass burning plumes appear to be overestimated.

For a particular case study (2 July 2016), we conducted simulations for realistic conditions and for idealized experiments, with a passive tracer initially restricted entirely to the $2-4 \mathrm{~km}$ layer. The main results are schematically illustrated in Fig. 12, showing an ensemble of clouds with dif- 
ferent vertical extents. The biomass burning aerosol is first transported out to the tropical Atlantic with a strong easterly flow at midlevels (yellow arrow in Fig. 12). Its base is often well above the usually shallow oceanic PBL (sketched to reach $800 \mathrm{~m}$ in Fig. 12). Both turbulent diffusion and cloudinduced mixing cause a vertical transport to below $1 \mathrm{~km}$ with the latter contributing more than two-thirds over most areas. Individual cloud-induced mixing events can be detected that are associated with deeper clouds, precipitation, and downdraughts, leading to surface cold pools. Concentrations of the biomass burning plume aerosol below $1 \mathrm{~km}$ reach about $15 \%$ of the initial mass in the $2-4 \mathrm{~km}$ layer after $2 \mathrm{~d}$ in our tracer experiments. Details of the mixing depend crucially on cloud depth and precipitation intensity (as indicated by solid and stippled arrows in Fig. 12). Once in the lower layers biomass burning can be carried northward with the southerly or southwesterly monsoon winds (indicated by yellow arrows in Fig. 12). It is conceivable (but not shown here) that the strong shear between near-surface southerlies and midlevel easterlies helps tilting convective clouds when they form and thereby increases evaporation at cloud edges, downdraught formation, and mixing. In addition, we found a meridional gradient in the effectiveness of downward transport irrespective of the actual sources of biomass burning aerosol. The largest PBL input occurs over the warm waters of the Southern Hemisphere (around $7^{\circ} \mathrm{S}$ ) with a marked decrease towards the equatorial cold tongue. Towards the north, SST increase again but mixing efficiency does not reach the same levels as in the Southern Hemisphere, possibly due to differences in vertical stability.

This study is largely based on a case study to illustrate the potential importance of downward cloud venting over the Gulf of Guinea. Further investigations are needed based on longer simulations and other models to get more robust statistics. Moreover, the tracer experiment we present here was performed for an inert tracer such as $\mathrm{CO}$ with no sedimentation and no deposition. The central African biomass burning plume contains large amounts of aerosols, which do sediment and can be washed out by rainfall into the ocean. The magnitude of this, however, remains an open question that needs to be addressed in future studies.

Data availability. The underlying research data are available upon request from the corresponding author.

Author contributions. AD, BV, KOO, and VY conceived and designed the study. AD, BV, and HV developed the model codes and carried out the simulations. $\mathrm{AD}, \mathrm{PK}, \mathrm{BV}$, and $\mathrm{KOO}$ contributed to the literature, data analysis and interpretation, and article writing. PK, BV, SS, ETN, and VY contributed to the article revision.
Competing interests. The authors declare that they have no conflict of interest.

Special issue statement. This article is part of the special issue "Results of the project "Dynamics-aerosol-chemistry-cloud interactions in West Africa" (DACCIWA) (ACP/AMT inter-journal SI)". It is not associated with a conference.

Acknowledgements. The research leading to these results has received funding from West African Science Service Centre on Climate Change and Adapted Land Use (WASCAL) and got support from European Union 7th Framework Programme (FP7/20072013) under grant agreement no. 603502 (EU project DACCIWA: Dynamics-aerosol-chemistry-cloud interactions in West Africa). The first author would like to thank the Aerosols, Trace Gases and Climate Processes, Institute of Meteorology and Climate Research - Department Troposphere Research (IMK-TRO) research group for hosting her during 1 year at Karlsruhe Institute of Technology (KIT) and for their valuable contribution to the paper. We acknowledge the constructive comments from two anonymous reviewers that have helped significantly to improve the article.

Financial support. This work was funded by the German Federal Ministry of Education and Research (BMBF) through the West African Science Service Center on Climate Change and Adapted Land Use (WASCAL).

Review statement. This paper was edited by Susan van den Heever and reviewed by two anonymous referees.

\section{References}

Adler, B., Babić, K., Kalthoff, N., Lohou, F., Lothon, M., Dione, C., Pedruzo-Bagazgoitia, X., and Andersen, H.: Nocturnal low-level clouds in the atmospheric boundary layer over southern West Africa: an observation-based analysis of conditions and processes, Atmos. Chem. Phys., 19, 663-681, https://doi.org/10.5194/acp-19-663-2019, 2019.

Athanasopoulou, E., Vogel, H., Vogel, B., Tsimpidi, A. P., Pandis, S. N., Knote, C., and Fountoukis, C.: Modeling the meteorological and chemical effects of secondary organic aerosols during an EUCAARI campaign, Atmos. Chem. Phys., 13, 625-645, https://doi.org/10.5194/acp-13-625-2013, 2013.

Bahino, J., Yoboué, V., Galy-Lacaux, C., Adon, M., Akpo, A., Keita, S., Liousse, C., Gardrat, E., Chiron, C., Ossohou, M., Gnamien, S., and Djossou, J.: A pilot study of gaseous pollutants' measurement $\left(\mathrm{NO}_{2}, \mathrm{SO}_{2}, \mathrm{NH}_{3}, \mathrm{HNO}_{3}\right.$ and $\left.\mathrm{O}_{3}\right)$ in Abidjan, Côte d'Ivoire: contribution to an overview of gaseous pollution in African cities, Atmos. Chem. Phys., 18, 5173-5198, https://doi.org/10.5194/acp-18-5173-2018, 2018.

Baldauf, M., Seifert, A., Förstner, J., Majewski, D., Raschendorfer, M., and Reinhardt, T.: Operational Convective-Scale Numerical Weather Prediction with the COSMO Model: Descrip- 
tion and Sensitivities, Mon. Weather Rev., 139, 3887-3905, https://doi.org/10.1175/MWR-D-10-05013.1, 2011.

Bangert, M., Nenes, A., Vogel, B., Vogel, H., Barahona, D., Karydis, V. A., Kumar, P., Kottmeier, C., and Blahak, U.: Saharan dust event impacts on cloud formation and radiation over Western Europe, Atmos. Chem. Phys., 12, 4045-4063, https://doi.org/10.5194/acp-12-4045-2012, 2012.

Barbosa, P. M., Stroppiana, D., Grégoire, J. M., and Pereira, J. M. C.: An assessment of vegetation fire in Africa (1981-1991): Burned areas, burned biomass, and atmospheric emissions, Global Biogeochem. Cy., 13, 933-950, https://doi.org/10.1029/1999GB900042, 1999.

Betts, A. K., Gatti, L. V., Cordova, A. M., Silva Dias, M. A. F., and Fuentes, J. D.: Transport of ozone to the surface by convective downdrafts at night, J. Geophys. Res.-Atmos., 107, 1-7, https://doi.org/10.1029/2000JD000158, 2002.

Brito, J., Freney, E., Dominutti, P., Borbon, A., Haslett, S. L., Batenburg, A. M., Colomb, A., Dupuy, R., Denjean, C., Burnet, F., Bourriane, T., Deroubaix, A., Sellegri, K., Borrmann, S., Coe, H., Flamant, C., Knippertz, P., and Schwarzenboeck, A.: Assessing the role of anthropogenic and biogenic sources on $\mathrm{PM}_{1}$ over southern West Africa using aircraft measurements, Atmos. Chem. Phys., 18, 757-772, https://doi.org/10.5194/acp-18-7572018, 2018.

Buchholz, R. R., Deeter, M. N., Worden, H. M., Gille, J., Edwards, D. P., Hannigan, J. W., Jones, N. B., Paton-Walsh, C., Griffith, D. W. T., Smale, D., Robinson, J., Strong, K., Conway, S., Sussmann, R., Hase, F., Blumenstock, T., Mahieu, E., and Langerock, B.: Validation of MOPITT carbon monoxide using ground-based Fourier transform infrared spectrometer data from NDACC, Atmos. Meas. Tech., 10, 1927-1956, https://doi.org/10.5194/amt10-1927-2017, 2017.

Buchwitz, M., Khlystova, I., Bovensmann, H., and Burrows, J. P.: Three years of global carbon monoxide from SCIAMACHY: comparison with MOPITT and first results related to the detection of enhanced CO over cities, Atmos. Chem. Phys., 7, 23992411, https://doi.org/10.5194/acp-7-2399-2007, 2007.

Ching, J. K. S., Shipley, S. T., and Browell, E. V.: Evidence for cloud venting of mixed layer ozone and aerosols, Atmos. Environ., 22, 225-242, https://doi.org/10.1016/0004-6981(88)900303, 1988.

Clerbaux, C., George, M., Turquety, S., Walker, K. A., Barret, B., Bernath, P., Boone, C., Borsdorff, T., Cammas, J. P., Catoire, V., Coffey, M., Coheur, P.-F., Deeter, M., De Mazière, M., Drummond, J., Duchatelet, P., Dupuy, E., de Zafra, R., Eddounia, F., Edwards, D. P., Emmons, L., Funke, B., Gille, J., Griffith, D. W. T., Hannigan, J., Hase, F., Höpfner, M., Jones, N., Kagawa, A., Kasai, Y., Kramer, I., Le Flochmoën, E., Livesey, N. J., López-Puertas, M., Luo, M., Mahieu, E., Murtagh, D., Nédélec, P., Pazmino, A., Pumphrey, H., Ricaud, P., Rinsland, C. P., Robert, C., Schneider, M., Senten, C., Stiller, G., Strandberg, A., Strong, K., Sussmann, R., Thouret, V., Urban, J., and Wiacek, A.: CO measurements from the ACE-FTS satellite instrument: data analysis and validation using ground-based, airborne and spaceborne observations, Atmos. Chem. Phys., 8, 2569-2594, https://doi.org/10.5194/acp-8-2569-2008, 2008.

Cook, K. H.: Generation of the African easterly jet and its role in determining West African precipitation, J.
Climate, $\quad 12, \quad 1165-1184, \quad$ https://doi.org/10.1175/15200442(1999)012<1165:GOTAEJ>2.0.CO;2, 1999.

Cotton, W. R., Alexander, G. D., Hertenstein, R., Walko, R. L., McAnelly, R. L., and Nicholls, M.: Cloud venting - A review and some new global annual estimates, Earth Sci. Rev., 39, 169206, https://doi.org/10.1016/0012-8252(95)00007-0, 1995.

Das, S., Harshvardhan, H., Bian, H., Chin, M., Curci, G., Protonotariou, A. P., Mielonen, T., Zhang, K., Wang, H., and Liu, X.: Biomass burning aerosol transport and vertical distribution over the South African-Atlantic region, J. Geophys. Res., 122, 63916415, https://doi.org/10.1002/2016JD026421, 2017.

Dee, D. P., Uppala, S. M., Simmons, A. J., Berrisford, P., Poli, P., Kobayashi, S., Andrae, U., Balmaseda, M. A., Balsamo, G., Bauer, P., Bechtold, P., Beljaars, A. C. M., van de Berg, L., Bidlot, J., Bormann, N., Delsol, C., Dragani, R., Fuentes, M., Geer, A. J., Haimberger, L., Healy, S. B., Hersbach, H., Hólm, E. V., Isaksen, L., Kållberg, P., Köhler, M., Matricardi, M., Mcnally, A. P., Monge-Sanz, B. M., Morcrette, J. J., Park, B. K., Peubey, C., de Rosnay, P., Tavolato, C., Thépaut, J. N., and Vitart, F.: The ERA-Interim reanalysis: Configuration and performance of the data assimilation system, Q. J. Roy. Meteor. Soc., 137, 553-597, https://doi.org/10.1002/qj.828, 2011.

Deetz, K. and Vogel, B.: Development of a new gas-flaring emission dataset for southern West Africa, Geosci. Model Dev., 10, 16071620, https://doi.org/10.5194/gmd-10-1607-2017, 2017.

Deetz, K., Vogel, H., Knippertz, P., Adler, B., Taylor, J., Coe, H., Bower, K., Haslett, S., Flynn, M., Dorsey, J., Crawford, I., Kottmeier, C., and Vogel, B.: Numerical simulations of aerosol radiative effects and their impact on clouds and atmospheric dynamics over southern West Africa, Atmos. Chem. Phys., 18, 9767-9788, https://doi.org/10.5194/acp-18-9767-2018, 2018.

Deroubaix, A., Menut, L., Flamant, C., Brito, J., Denjean, C., Dreiling, V., Fink, A., Jambert, C., Kalthoff, N., Knippertz, P., Ladkin, R., Mailler, S., Maranan, M., Pacifico, F., Piguet, B., Siour, G., and Turquety, S.: Diurnal cycle of coastal anthropogenic pollutant transport over southern West Africa during the DACCIWA campaign, Atmos. Chem. Phys., 19, 473-497, https://doi.org/10.5194/acp-19-473-2019, 2019.

Dickerson, R. R., Huffman, G. J., Luke, W. T., Nunnermacker, L. J., Pickering, K. E., Leslie, A. C. D., Lindsey, C. G., Slinn, W. G. N., Kelly, T. J., Daum, P. H., Delany, A. C., Greenberg, J. P., Zimmerman, P. R., Boatman, J. F., Ray, J. D., and Stedman, D. H.: Thunderstorms: An important mechanism in the transport of air pollutants, Science, 235, 460-465, https://doi.org/10.1126/science.235.4787.460, 1987.

Djossou, J., Léon, J.-F., Akpo, A. B., Liousse, C., Yoboué, V., Bedou, M., Bodjrenou, M., Chiron, C., Galy-Lacaux, C., Gardrat, E., Abbey, M., Keita, S., Bahino, J., Touré N'Datchoh, E., Ossohou, M., and Awanou, C. N.: Mass concentration, optical depth and carbon composition of particulate matter in the major southern West African cities of Cotonou (Benin) and Abidjan (Côte d'Ivoire), Atmos. Chem. Phys., 18, 6275-6291, https://doi.org/10.5194/acp-18-6275-2018, 2018.

Doumbia, M., Toure, N. E., Silue, S., Yoboue, V., Diedhiou, A., and Hauhouot, C.: Emissions from the road traffic of West African cities: Assessment of vehicle fleet and fuel consumption, Energies, 11, 1-16, https://doi.org/10.3390/en11092300, 2018.

Drummond, J. R. and Mand, G. S.: The measurements of pollution in the troposphere (MOPITT) instrument: Over- 
all performance and calibration requirements, J. Atmos. Ocean. Tech., 13, 314-320, https://doi.org/10.1175/15200426(1996)013<0314:TMOPIT>2.0.CO;2, 1996.

Eastman, R., Warren, S. G., and Hahn, C. J.: Variations in cloud cover and cloud types over the Ocean from surface observations, 1954-2008, J. Climate, 24, 5914-5934, https://doi.org/10.1175/2011JCLI3972.1, 2011.

Edgar: EDGAR - Emission Database for Global Atmospheric Research, Glob. Emiss. EDGAR v4.2 (November 2011), https://doi.org/10.2904/EDGARv4.2, 2010.

Edwards, D. P., Halvorson, C. M., and Gille, J. C.: Radiative transfer modeling for the EOS Terra satellite Measurement of Pollution in the Troposphere (MOPITT) instrument, J. Geophys. Res.-Atmos., 104, 16755-16775, https://doi.org/10.1029/1999JD900167, 1999.

Emmons, L. K., Walters, S., Hess, P. G., Lamarque, J.-F., Pfister, G. G., Fillmore, D., Granier, C., Guenther, A., Kinnison, D., Laepple, T., Orlando, J., Tie, X., Tyndall, G., Wiedinmyer, C., Baughcum, S. L., and Kloster, S.: Description and evaluation of the Model for Ozone and Related chemical Tracers, version 4 (MOZART-4), Geosci. Model Dev., 3, 43-67, https://doi.org/10.5194/gmd-3-43-2010, 2010.

Flamant, C., Deroubaix, A., Chazette, P., Brito, J., Gaetani, M., Knippertz, P., Fink, A. H., de Coetlogon, G., Menut, L., Colomb, A., Denjean, C., Meynadier, R., Rosenberg, P., Dupuy, R., Dominutti, P., Duplissy, J., Bourrianne, T., Schwarzenboeck, A., Ramonet, M., and Totems, J.: Aerosol distribution in the northern Gulf of Guinea: local anthropogenic sources, long-range transport, and the role of coastal shallow circulations, Atmos. Chem. Phys., 18, 12363-12389, https://doi.org/10.5194/acp-18-123632018, 2018a.

Flamant, C., KniPPertz, P., Fink, A. H., Akpo, A., BrooKs, B., CHiu, C. J., Coe, H., Danuor, S., Evans, M., JegeDe, O., Kalthoff, N., Konaré, A., Liousse, C., Lohou, F., Mari, C., Schlager, H., Schwarzenboeck, A., Adler, B., Amekudzi, L., Aryee, J., Ayoola, M., BatenBurg, A. M., BessarDon, G., Borrmann, S., Brito, J., Bower, K., Burnet, F., Catoire, V., ColomB, A., DenJean, C., Fosuamankwah, K., Hill, P. G., Lee, J., Lothon, M., Maranan, M., Marsham, J., Meynadier, R., Ngamini, J. B., Rosenberg, P., Sauer, D., Smith, V., Stratmann, G., Taylor, J. W., Voigt, C., and Yoboué, V.: The dynamics aerosol chemistry cloud interactions in west Africa field campaign, B. Am. Meteorol. Soc., 99, 83104, https://doi.org/10.1175/BAMS-D-16-0256.1, 2018b.

Flossmann, A. I. and Wobrock, W.: Venting of gases by convective clouds, J. Geophys. Res., 101, 18639, https://doi.org/10.1029/96JD01581, 1996.

Gerken, T., Wei, D., Chase, R. J., Fuentes, J. D., Schumacher, C., Machado, L. A. T., Andreoli, R. V., Chamecki, M., Ferreira de Souza, R. A., Freire, L. S., Jardine, A. B., Manzi, A. O., Nascimento dos Santos, R. M., von Randow, C., dos Santos Costa, P., Stoy, P. C., Tóta, J., and Trowbridge, A. M.: Downward transport of ozone rich air and implications for atmospheric chemistry in the Amazon rainforest, Atmos. Environ., 124, 64-76, https://doi.org/10.1016/j.atmosenv.2015.11.014, 2016.

Halland, J. J., Fuelberg, H. E., Pickering, K. E., and Luo, M.: Identifying convective transport of carbon monoxide by comparing remotely sensed observations from TES with cloud modeling simulations, Atmos. Chem. Phys., 9, 4279-4294, https://doi.org/10.5194/acp-9-4279-2009, 2009.
Hannak, L., Knippertz, P., Fink, A. H., Kniffka, A., and Pante, G.: AMERICAN METEOROLOGICAL This is a preliminary PDF of the author-produced, Am. Meteorogical Soc., 30, 1665-1687, https://doi.org/10.1175/JCLI-D-16-0451.1, 2017.

Hao, W. M. and Liu, M. H.: Spatial and temporal distribution of tropical biomass burning, Global Biogeochem. Cy., 8, 495-503, https://doi.org/10.1029/94GB02086, 1994.

Haslett, S. L., Taylor, J. W., Evans, M., Morris, E., Vogel, B., Dajuma, A., Brito, J., Batenburg, A. M., Borrmann, S., Schneider, J., Schulz, C., Denjean, C., Bourrianne, T., Knippertz, P., Dupuy, R., Schwarzenböck, A., Sauer, D., Flamant, C., Dorsey, J., Crawford, I., and Coe, H.: Remote biomass burning dominates southern West African air pollution during the monsoon, Atmos. Chem. Phys., 19, 15217-15234, https://doi.org/10.5194/acp-1915217-2019, 2019.

Hill, P. G., Allan, R. P., Chiu, J. C., and Stein, T. H. M.: Journal of Geophysical Research?: Atmospheres and comparison to climate models, J. Geophys. Res.-Atmos., 121, 10857-10879, https://doi.org/10.1002/2016JD025246, 2016.

Hou, A. Y., Kakar, R. K., Neeck, S., Azarbarzin, A. A., Kummerow, C. D., Kojima, M., Oki, R., Nakamura, K., and Iguchi, T.: The global precipitation measurement mission, B. Am. Meteorol. Soc., 95, 701-722, https://doi.org/10.1175/BAMS-D-1300164.1, 2014

Huffman, G. J., Bolvin, D. T., Braithwaite, D., Hsu, K., Joyce, R., Kidd, C., Nelkin, E. J., Sorooshian, S., Tan, T., and Xie, P.: NASA Global Precipitation Measurement (GPM) Integrated Multi-satellitE Retrievals for GPM (IMERG), Algorithm Theor. Basis Doc., (February), 1-31, 2018.

Ito, A. and Penner, J. E.: Global estimates of biomass burning emissions based on satellite imagery for the year 2000, J. Geophys. Res.-Atmos., 109, 1-18, https://doi.org/10.1029/2003JD004423, 2004.

Janicot, S., Thorncroft, C. D., Ali, A., Asencio, N., Berry, G., Bock, O., Bourles, B., Caniaux, G., and Chauvin, F.: ReviewAMMA field experiment in 2006.pdf, 26, 2569-2595, 2008.

Jonker, H. J. J., Heus, T., and Sullivan, P. P.: A refined view of vertical mass transport by cumulus convection, Geophys. Res. Lett., 35, 1-5, https://doi.org/10.1029/2007GL032606, 2008.

Kaiser, J. W., Heil, A., Andreae, M. O., Benedetti, A., Chubarova, N., Jones, L., Morcrette, J.-J., Razinger, M., Schultz, M. G., Suttie, M., and van der Werf, G. R.: Biomass burning emissions estimated with a global fire assimilation system based on observed fire radiative power, Biogeosciences, 9, 527-554, https://doi.org/10.5194/bg-9-527-2012, 2012.

Kar, J., Jones, D. B. A., Drummond, J. R., Attie, J. L., Liu, J., Zou, J., and Nichitiu, F.: Measurement of low-altitude CO over the Indian subcontinent by MOPITT, 113, 1-13, https://doi.org/10.1029/2007JD009362, 2008.

Katoshevski, D., Nenes, A., and Seinfeld, J. H.: A study of processes that govern the maintenance of aerosols in the marine boundary layer, J. Aerosol Sci., 30, 503-532, https://doi.org/10.1016/S0021-8502(98)00740-X, 1999.

Kaufman, Y. J., Koren, I., Remer, L. A., Rosenfeld, D., and Rudich, Y.: The effect of smoke, dust, and pollution aerosol on shallow cloud development over the Atlantic Ocean, P. Natl. Acad. Sci. USA, 102, 11207-11212, https://doi.org/10.1073/pnas.0505191102, 2005. 
Knippertz, P., Evans, M. J., Field, P. R., Fink, A. H., Liousse, C., and Marsham, J. H.: The possible role of local air pollution in climate change in West Africa, Nat. Clim. Chang., 815-822, https://doi.org/10.1038/nclimate2727, 2015.

Knippertz, P., Fink, A. H., Deroubaix, A., Morris, E., Tocquer, F., Evans, M. J., Flamant, C., Gaetani, M., Lavaysse, C., Mari, C., Marsham, J. H., Meynadier, R., Affo-Dogo, A., Bahaga, T., Brosse, F., Deetz, K., Guebsi, R., Latifou, I., Maranan, M., Rosenberg, P. D., and Schlueter, A.: A meteorological and chemical overview of the DACCIWA field campaign in West Africa in June-July 2016, Atmos. Chem. Phys., 17, 10893-10918, https://doi.org/10.5194/acp-17-10893-2017, 2017.

Knote, C., Brunner, D., Vogel, H., Vogel, B., and Lohmann, U.: Online-coupled chemistry and aerosols: COSMO-ART model performance, 2010.

Konare, A., Zakey, A. S., Solmon, F., Giorgi, F., Rauscher, S., Ibrah, S., and $\mathrm{Bi}, \mathrm{X}$.: A regional climate modeling study of the effect of desert dust on the West African monsoon, J. Geophys. Res.-Atmos., 113, 1-15, https://doi.org/10.1029/2007JD009322, 2008.

Kreidenweis, S., Zhang, Y. and Taylor, G. R.: The Effects of Clouds on Aerosol and Chemical Species Production and Distribution, Part III: Aerosol Model Description and Sensitivity Analysis, J. Geophys. Res., 102, 23867-23882, https://doi.org/10.1175/15200469(1998)055<0921:teocoa>2.0.co;2, 1997.

Lelieveld, J., Fnais, M., Evans, J. S., Giannadaki, D., and Pozzer, A.: The contribution of outdoor air pollution sources to premature mortality on a global scale, Nature, 525, 367-371, https://doi.org/10.1038/nature15371, 2015.

Liousse, C., Assamoi, E., Criqui, P., Granier, C., and Rosset, R.: Explosive growth in African combustion emissions from 2005 to 2030, Environ. Res. Lett., 9, https://doi.org/10.1088/17489326/9/3/035003, 2014.

Marais, E. A. and Wiedinmyer, C.: Air Quality Impact of Diffuse and Inefficient Combustion Emissions in Africa (DICE-Africa), Environ. Sci. Technol., 50, 10739-10745, https://doi.org/10.1021/acs.est.6b02602, 2016.

Mari, C., Jacob, D. J., and Bechtold, P.: Transport and scavenging of soluble gases in a deep convective cloud, J. Geophys. Res.-Atmos., 105, 22255-22267, https://doi.org/10.1029/2000JD900211, 2000.

Mari, C. H., Cailley, G., Corre, L., Saunois, M., Attié, J. L., Thouret, V., and Stohl, A.: Tracing biomass burning plumes from the Southern Hemisphere during the AMMA 2006 wet season experiment, Atmos. Chem. Phys., 8, 3951-3961, https://doi.org/10.5194/acp-8-3951-2008, 2008.

Menut, L., Flamant, C., Turquety, S., Deroubaix, A., Chazette, P., and Meynadier, R.: Impact of biomass burning on pollutant surface concentrations in megacities of the Gulf of Guinea, Atmos. Chem. Phys., 18, 2687-2707, https://doi.org/10.5194/acp18-2687-2018, 2018.

N'Datchoh, E. T., Konaré, A., Diedhiou, A., Diawara, A., Quansah, E., and Assamoi, P.: Effects of climate variability on savannah fire regimes in West Africa, Earth Syst. Dynam., 6, 161-174, https://doi.org/10.5194/esd-6-161-2015, 2015.

N'Datchoh, E. T., Diallo, I., Konaré, A., Silué, S., Ogunjobi, K. O., Diedhiou, A., and Doumbia, M.: Dust induced changes on the
West African summer monsoon features, Int. J. Climatol., 38, 452-466, https://doi.org/10.1002/joc.5187, 2018.

Pan, L., Gille, J. C., Edwards, D. P., Bailey, P. L., and Rodgers, C. D.: Retrieval of tropospheric carbon monoxide for the MOPITT experiment, J. Geophys. Res.-Atmos., 103, 32277-32290, https://doi.org/10.1029/98JD01828, 1998.

Parker, D. J., Burton, R. R., Diongue-Niang, A., Ellis, R. J., Felton, M., Taylor, C. M., Thorncroft, C. D., Bessemoulin, P., and Tompkins, A. M.: The diurnal cycle of the West African monsoon circulation, Q. J. Roy. Meteor. Soc., 131, 2839-2860, https://doi.org/10.1256/qj.04.52, 2005.

Pickering, K. E., Thompson, A. M., Wang, Y., Tao, W. K., McNamara, D. P., Kirchhoff, V. W. J. H., Heikes, B. G., Sachse, G. W., Bradshaw, J. D., Gregory, G. L., and Blake, D. R.: Convective transport of biomass burning emissions over Brazil during TRACE A, J. Geophys. Res.-Atmos., 101, 23993-24012, 1996.

Platnick, S., Meyer, K. G., King, M. D., Wind, G., Amarasinghe, N., Marchant, B., Arnold, G. T., Zhang, Z., Hubanks, P. A., Holz, R. E., Yang, P., Ridgway, W. L., and Riedi, J.: The MODIS Cloud Optical and Microphysical Products: Collection 6 Updates and Examples from Terra and Aqua, IEEE Trans. Geosci. Remote Sens., 55, 502-525, https://doi.org/10.1109/TGRS.2016.2610522, 2017.

Raes, F.: Entrainment of free tropospheric aerosol as a regulation mechanism for cloud dondensation nuclei in the remote marine boundary layer, 100, 2893-2903, 1995.

Raji, K. B., Ogunjobi, K. O., and Akinsanola, A. A.: Radiative effects of dust aerosol on West African climate using simulations from RegCM4, Model. Earth Syst. Environ., 3, 34, https://doi.org/10.1007/s40808-017-0295-y, 2017.

Seifert, A. and Beheng, K. D.: A two-moment cloud microphysics parameterization for mixed-phase clouds, Part 1: Model description, Meteorol. Atmos. Phys., 92, 45-66, https://doi.org/10.1007/s00703-005-0112-4, 2006.

Solmon, F., Mallet, M., Elguindi, N., Giorgi, F., Zakey, A., and Konaré, A.: Dust aerosol impact on regional precipitation over western Africa, mechanisms and sensitivity to absorption properties, Geophys. Res. Lett., 24, 35, https://doi.org/10.1029/2008GL035900, 2008.

Stanelle, T., Vogel, B., Vogel, H., Bäumer, D., and Kottmeier, C.: Feedback between dust particles and atmospheric processes over West Africa during dust episodes in March 2006 and June 2007, Atmos. Chem. Phys., 10, 10771-10788, https://doi.org/10.5194/acp-10-10771-2010, 2010.

Stowe, L. L., Jacobowitz, H., Ohring, G., Knapp, K. R., and Nalli, N. R.: The Advanced Very High Resolution Radiometer (AVHRR) Pathfinder Atmosphere (PATMOS) climate dataset: Initial analyses and evaluations, J. Climate, 15, 1243-1260, https://doi.org/10.1175/15200442(2002)015<1243:TAVHRR>2.0.CO;2, 2002.

Turquety, S., Clerbaux, C., Law, K., Coheur, P.-F., Cozic, A., Szopa, S., Hauglustaine, D. A., Hadji-Lazaro, J., Gloudemans, A. M S., Schrijver, H., Boone, C. D., Bernath, P. F., and Edwards, D. P.: CO emission and export from Asia: an analysis combining complementary satellite measurements (MOPITT, SCIAMACHY and ACE-FTS) with global modeling, Atmos. Chem. Phys., 8, 5187-5204, https://doi.org/10.5194/acp-8-5187-2008, 2008. 
Vogel, B., Vogel, H., Bäumer, D., Bangert, M., Lundgren, K., Rinke, R., and Stanelle, T.: The comprehensive model system COSMOART - Radiative impact of aerosol on the state of the atmosphere on the regional scale, Atmos. Chem. Phys., 9, 8661-8680, https://doi.org/10.5194/acp-9-8661-2009, 2009.

Walter, C., Freitas, S. R., Kottmeier, C., Kraut, I., Rieger, D., Vogel, H., and Vogel, B.: The importance of plume rise on the concentrations and atmospheric impacts of biomass burning aerosol, Atmos. Chem. Phys., 16, 9201-9219, https://doi.org/10.5194/acp16-9201-2016, 2016.

Wang, J., Krejci, R., Giangrande, S., Kuang, C., Barbosa, H. M. J., Brito, J., Carbone, S., Chi, X., Comstock, J., Ditas, F., Lavric, J., Manninen, H. E., Mei, F., Moran-Zuloaga, D., Pöhlker, C., Pöhlker, M. L., Saturno, J., Schmid, B., Souza, R. A. F., Springston, S. R., Tomlinson, J. M., Toto, T., Walter, D., Wimmer, D., Smith, J. N., Kulmala, M., Machado, L. A. T., Artaxo, P., Andreae, M. O., Petäjä, T., and Martin, S. T.: Amazon boundary layer aerosol concentration sustained by vertical transport during rainfall, Nature, 539, 416-419, https://doi.org/10.1038/nature19819, 2016.

Van der Werf, G. R., Randerson, J. T., Collatz, G. J., and Giglio, L.: Carbon emissions from fires in tropical and subtropical ecosystems, Glob. Chang. Biol., 9, 547-562, https://doi.org/10.1046/j.1365-2486.2003.00604.x, 2003.
Wu, M. L. C., Reale, O., Schubert, S. D., Suarez, M. J., Koster, R. D., and Pegion, P. J.: African easterly jet: Structure and maintenance, J. Climate, 22, 4459-4480, https://doi.org/10.1175/2009JCLI2584.1, 2009.

Yin, Y., Parker, D. J., and Carslaw, K. S.: Simulation of trace gas redistribution by convective clouds - Liquid phase processes, Atmos. Chem. Phys., 1, 19-36, https://doi.org/10.5194/acp-1-192001, 2001.

Zängl, G., Reinert, D., Rípodas, P., and Baldauf, M.: The ICON (ICOsahedral Non-hydrostatic) modelling framework of DWD and MPI-M: Description of the non-hydrostatic dynamical core, Q. J. Roy. Meteor. Soc., 141, 563-579, https://doi.org/10.1002/qj.2378, 2015.

Zuidema, P., Redemann, J., Haywood, J., Wood, R., Piketh, S., Hipondoka, M., and Formenti, P.: Smoke and clouds above the southeast Atlantic: Upcoming field campaigns probe absorbing aerosol's impact on climate, B. Am. Meteorol. Soc., 97, 11311135, https://doi.org/10.1175/BAMS-D-15-00082.1, 2016. 